TOMASZ KRZYŻOWSKI

(D) https://orcid.org/0000-0001-7193-5661

Ośrodek Badań nad Kulturą Ormiańską w Polsce

Polska Akademia Umiejętności, Kraków

\title{
NAUCZANIE JĘZYKA ORMIAŃSKIEGO NA UNIWERSYTECIE LWOWSKIM W LATACH 1904-1939
}

\begin{abstract}
Abstrakt: Pierwsze próby wprowadzenia lektoratu języka ormiańskiego na Uniwersytecie Lwowskim zrodziły się na początku XX wieku. W latach 1904-1933 prowadził go ksiądz Bogdan Dawidowicz. Na zajęcia uczęszczali klerycy archidiecezji ormiańskokatolickiej, językoznawcy, orientaliści oraz wolni słuchacze. Studenci zapoznawali się z gramatyką i literaturą ormiańską, między innymi z dziełami Mojżesza z Chorenu i twórczością Raffiego (Hakoba Melika Hakobiana), oraz ze specyfiką rozwoju języka ormiańskiego w Polsce. Po śmierci księdza Dawidowicza lektorat kontynuował Garabed Keuprulian, koncentrując się na języku zachodnioormiańskim. W okresie międzywojennym wykłady z języka i klasycznej literatury ormiańskiej prowadził na Uniwersytecie Jana Kazimierza we Lwowie Andrzej Gawroński, natomiast Jerzy Kuryłowicz wykładał język staroormiański w ujęciu historyczno-porównawczym. W omawianym okresie środowisko uniwersyteckie we Lwowie oraz działacze Archidiecezjalnego Związku Ormian podejmowali również inicjatywy wydawnicze mające na celu popularyzację wiedzy i pogłębienie studiów z zakresu języka ormiańskiego.
\end{abstract}

Słowa kluczowe: armenistyka, język ormiański, Uniwersytet Lwowski, Bogdan Dawidowicz, Garabed Keuprulian, Andrzej Gawroński, Jerzy Kuryłowicz 
Nauczanie języka ormiańskiego ${ }^{1}$ w Polsce ma długą tradycję i wiąże się z działalnością i rozwojem Kościoła ormiańskiego ${ }^{2}$. Zajęcia prowadzone były przede wszystkim w szkółkach przy ormiańskich świątyniach, kształcono chłopców na poziomie elementarnym. Uczono czytania, pisania, gramatyki, śpiewu kościelnego i klasycznego języka ormiańskiego. W nauce bazowano głównie na Piśmie Świętym i księgach o charakterze religijnym. Choć w mowie codziennej Ormianie mieszkający w Polsce posługiwali się przeważnie językami kipczackim (do XVII wieku) i polskim, to w programie nauczania dawnych szkół ormiańskich grabar zajmował pierwszorzędne miejsce. Uczono zatem języka sakralnego, tak jak w przypadku wyznawców Kościoła rzymskokatolickiego - łaciny. Tym sposobem w mniejszym lub większym stopniu uczniowie zapoznawali się z językiem staroormiańskim, z którym mieli kontakt także podczas uczestnictwa w ormiańskiej liturgii ${ }^{3}$. Szkółki ormiańskie zlikwidowane zostały przez władze austriackie pod koniec XVIII wieku, wprowadzono wtedy na ziemiach zabranych Polsce szkoły ludowe (elementarne): polskie, ruskie i niemieckie, z pominięciem jednak ormiańskich ${ }^{4}$.

Naukę klasycznego języka ormiańskiego pobierali też alumni Papieskiego Kolegium Ormiańskiego, prowadzonego przez zakon teatynów w latach 16651784 we Lwowie ${ }^{5}$. Kolegium kształciło przyszłych kapłanów lwowskiej archi-

${ }^{1}$ Na pojęcie ,język ormiański” składają się: język staroormiański - czyli klasyczny język ormiański, tak zwany grabar, powstały na początku V wieku po Chrystusie, używany jako język literacki Ormian do początku XIX wieku oraz do czasów współczesnych w ormiańskiej liturgii - oraz powstałe w XIX wieku literackie języki nowoormiańskie (aszcharabar) występujące w dwóch wariantach: wschodnim i zachodnim. Język wschodnioormiański ukształtował się na bazie dialektu erywańskiego i tyfliskiego. Posługują się nim Ormianie w Armenii, Iranie i Rosji. Język zachodnioormiański uformował się w Stambule i jest używany przez Ormian w Turcji, Libanie, krajach Europy Zachodniej, Ameryce Północnej i Południowej. Ponadto występują różne dialekty języka ormiańskiego, na przykład mieszkający w Kutach nad Czeremoszem Ormianie polscy posługiwali się dialektem nazywanym kuckim. Zob. A. Pisowicz, Gramatyka ormiańska (grabar - aszcharabar), Kraków 2014, s. 17-19. Składam podziękowanie profesorowi Andrzejowi Pisowiczowi za cenne wskazówki udzielone podczas pisania artykułu oraz udostępnienie literatury.

2 Podczas zgromadzenia duchowieństwa ormiańskiego w 1699 roku ówczesny koadiutor archidiecezji lwowskiej Deodat Nersesowicz zarządził, że „szkoła ma być przy każdym kościele, w której mają uczyć czytać i pisać po ormiańsku, gdzie by zaś proboszcz nie mógł utrzymać bakałarza; to niech sam uczy dzieci" (S. Barącz, Rys dziejów ormiańskich, Tarnopol 1869, s. 131-132).

${ }^{3}$ K. Stopka, Nieznane karty z dziejów szkolnictwa Ormian polskich. Szkoła kościelna (tybradun) do XVII wieku, w: Virtuti et ingenio. Ksiega pamiątkowa dedykowana Profesorowi Julianowi Dybcowi, red. A. K. Banach, Kraków 2013, s. 479, 482, 483, 484, 487, 495, 496.

${ }^{4}$ Idem, Tożsamość Ormian w Galicji, „Zeszyty Naukowe Uniwersytetu Jagiellońskiego”, „Prace Historyczne”, 144, 2017, 2, s. 337.

${ }^{5}$ E. Tryjarski, Ze studiów nad rękopisami i dialektem kipczackim Ormian polskich, 2, O nauce języków obcych w Kolegium teatyńskim we Lwowie, „Rocznik Orientalistyczny”, 23, 1960, 2, s. 38-43. 
diecezji ormiańskiej. Jednak i oni wskutek likwidacji kolegium przez zaborcę austriackiego po pierwszym rozbiorze Polski stracili dotychczasowe miejsce formacji i nauki - w tym języka ormiańskiego.

W wieku XIX pozostała tylko jedna ludowa szkoła ormiańska - w Kutach, istniała do lat 60. Nie zachowała się dokumentacja źródłowa na temat zasad jej funkcjonowania. W ostatnich latach działalności szkoła mieściła się w prywatnym domu w centrum miasteczka, nieopodal kościoła ormiańskiego. Wyposażenie było skromne i ograniczało się do ławek i tablicy. Była to szkoła jednoklasowa z jednym nauczycielem, skupiająca uczniów w różnym wieku o zróżnicowanym poziomie edukacji. Na lekcje przeznaczano cztery godziny dziennie. Program przewidywał edukację początkową z zakresu geografii i historii, uczono oczywiście czytania, pisania, rachowania, podstaw gramatyki, religii, języka ormiańskiego, śpiewu kościelnego oraz przekazywano najważniejsze wiadomości z gospodarstwa. Nauka trwała zazwyczaj dwa lata. Z podręczników uczniowie raczej nie korzystali. Języka ormiańskiego uczyli się z modlitewników drukowanych w grabarze ${ }^{6}$.

Jak podkreśla Mikołaj Mojzesowicz, autor wspomnienia o szkole kuckiej spisanego w latach 20. XX wieku, dzięki istnieniu szkoły i regularnej nauce języka ormiańskiego Ormianie w Kutach posługiwali się biegle językiem swoich przodków, w przeciwieństwie do Ormian zamieszkujących w innych miejscowościach Galicji, którzy tę umiejętność utracili. Trudno obecnie sprecyzować, jakiego wariantu języka ormiańskiego uczyły się dzieci w Kutach. Przypuszczalnie były to podstawy grabaru koniecznego do wyuczenia się modlitw i pieśni kościelnych. Niewykluczone, że uczniowie rozwijali też znajomość miejscowego dialektu, który poznawali w domach rodzinnych, ucząc się go od starszych pokoleń. Gdy szkołę zlikwidowano na mocy decyzji władz austriackich, miejscowi Ormianie posyłali swe dzieci do szkoły polskiej.

Po likwidacji kolegium teatyńskiego i szkół ormiańskich regularnego nauczania języka staro- i nowoormiańskiego w Galicji nie prowadzono już w żadnej instytucji edukacyjnej ${ }^{8}$. Prywatnych korepetycji udzielali niektórzy księża ormiańscy, którzy przekazywali wiedzę alumnom archidiecezji ormiańskiej, przygotowującym się do sprawowania liturgii ${ }^{9}$. Świeccy nie mieli sposobności do

${ }^{6}$ M. Mojzesowicz, Dawna szkoła ormiańska w Kutach, „Posłaniec św. Grzegorza”, 1, 1927,7 , s. 7.

7 Ibidem, s. 8.

${ }^{8}$ O nieudanej inicjatywie stworzenia takiej instytucji, podjętej w latach 80. XIX wieku, zob. A. A. Zięba, Idea powrotu Ormian z rozproszenia do narodowego państwa w historycznej ojczyźnie w świetle memoriałów Roberta Bogdanowicza z 1877 i 1884 roku w niniejszym numerze rocznika „Lehahayer”.

9 S. Donigiewicz, Dzieje nauczania języka ormiańskiego w Polsce i historia lektoratu tegoż języka w Uniwersytecie J[ana] K[azimierza] we Lwowie, „Posłaniec św. Grzegorza”, 7, 1933, 3-4, s. 36. 
nauki, a także - co trzeba podkreślić - nie musieli znać tych języków, gdyż posługiwali się na co dzień językiem polskim, względnie innymi językami, w zależności od wykonywanego zawodu. Sytuację tę w zasadzie trafnie komentował Eugeniusz Słuszkiewicz: „Od dosyć dawna już język ormiański - i to zazwyczaj tylko klasyczny - znają właściwie (jeśli odliczyć wyjątki, na ogół rzadkie) jedynie duchowni ormiańscy, którzy muszą się uczyć go dla odprawienia nabożeństwa w swoim obrządku"10. Z drugiej połowy XIX i z XX wieku znane są nieliczne przypadki nauczania dzieci języka ormiańskiego przez duchownych - i tylko w Kutach. Bogdan Dawidowicz, jako kleryk, przebywając w rodzinnej miejscowości, udzielał korepetycji chętnym osobom. Tamtejszy proboszcz, ksiądz Mikołaj Mojzesowicz, planował zorganizowanie dla dzieci stałych kursów dotyczących języka ormiańskiego. Gdy został przeniesiony do Tyśmienicy w 1910 roku, pomysł upadł. Lekcji języka ormiańskiego udzielał także przez krótki czas wikariusz kucki ksiądz Klemens Torbadżian, Ormianin pochodzący z Turcji1 ${ }^{11}$. Nie wiadomo, czy jakąkolwiek aktywność w kwestii nauczania ormiańskiego wykazywał jego następca ksiądz Bohos Kirmizjan, kapłan również urodzony w Turcji i przez wiele lat pracujący we lwowskiej archidiecezji ormiańskiej.

Pierwsze próby nauczania języka ormiańskiego na gruncie polskim na szczeblu uniwersyteckim zrodziły się w środowisku lwowskim na początku XX wieku. Wielkim orędownikiem uruchomienia lektoratu na Uniwersytecie Lwowskim ${ }^{12}$, a prawdopodobnie też ich pomysłodawcą, był profesor Jan Bołoz Antoniewicz historyk sztuki pochodzenia ormiańskiego. W swej pracy naukowej spotykał teksty w języku staroormiańskim i nie mogąc ich odczytać, korzystał z pomocy księdza Dawidowicza ${ }^{13}$. Wreszcie zaproponował mu poprowadzenie zajęć z języ-

${ }^{10}$ E. Słuszkiewicz, O charakterze języka ormiańskiego, jego pokrewieństwa z innymi językami i fazach rozwojowych, „Posłaniec św. Grzegorza”, 8, 1934, 3-4, s. 27.

${ }^{11}$ M. Mojzesowicz, Dawna szkoła, s. 8-9.

12 Do roku 1918 nazwa uczelni brzmiała: „C. K. Uniwersytet im. Cesarza Franciszka I”, a po odzyskaniu przez Polskę niepodległości - „Uniwersytet Jana Kazimierza” (dalej: UJK).

${ }^{13}$ Bogdan Dawidowicz urodził się w 1858 roku w rodzinie ormiańskiej w Kutach nad Czeremoszem. Był absolwentem gimnazjum we Lwowie i seminarium duchownego tamże. W 1882 roku przyjął święcenia kapłańskie w obrządku ormiańskokatolickim. Pracował duszpastersko we Lwowie jako wikariusz (1882-1884) oraz administrator i proboszcz w Suczawie (1884-1892). W 1892 roku został kanonikiem gremialnym kapituły ormiańskiej we Lwowie, a w roku 1924 - jej prepozytem. Równocześnie pełnił funkcje administracyjne w konsystorzu i sądzie arcybiskupim. Od młodości rozwijał zainteresowania językowe, nauczył się biegle języka ormiańskiego, a następnie uzupełniał wykształcenie w tym zakresie w klasztorach mechitarystów w Wiedniu i Wenecji. Odbył podróże na Wschód i do Europy Zachodniej, pogłębiając wiedzę i znajomość języków. Należał do kilku organizacji naukowych i kulturalnych: Komisji Orientalistycznej Polskiej Akademii Umiejętności w Krakowie, Towarzystwa Polsko-Ormiańskiego, Polskiego Towarzystwa Orientalistycznego, Archidiecezjalnego Związku Ormian. Był autorem kilku opracowań w języku ormiańskim i niemieckim oraz tłumaczeń z literatury ormiańskiej na język polski, opublikowanych w „Ruchu Katolickim” i „Posłańcu 
ka ormiańskiego na uniwersytecie. Kapłan początkowo wzbraniał się, tłumacząc problemami zdrowotnymi, jednak po dalszych namowach Antoniewicza wyraził zgodę $^{14}$ i 15 stycznia 1904 roku wniósł podanie do Rady Wydziału Filozoficznego Uniwersytetu Lwowskiego, wyrażając chęć prowadzenia lektoratu języka staro- i nowoormiańskiego.

Jako argument za utworzeniem lektoratu ksiądz Dawidowicz podał istnienie w Galicji Kościoła ormiańskokatolickiego i - co się z tym wiąże - konieczność kształcenia przyszłych duchownych. Podkreślił wielką wagę języka ormiańskiego w badaniach językoznawstwa porównawczego oraz bogatej spuścizny dzieł $\mathrm{z}$ historii i geografii spisanych $\mathrm{w}$ tym języku. Zaznaczył również, że na kilku europejskich uniwersytetach funkcjonują katedry języka ormiańskiego i prowadzone są $\mathrm{w}$ tym zakresie badania naukowe ${ }^{15}$. Zwrócił uwagę na potrzebę prowadzenia takich badań we Lwowie, gdyż zachowane tam źródła archiwalne w języku ormiańskim wymagają wykwalifikowanych specjalistów. Wskazał ponadto na swoje kompetencje językowe oraz fakt, że ormiański to jego język ojczysty. Do podania załączył dokument wydany przez mechitarystów wiedeńskich potwierdzający biegłą znajomość języka ormiańskiego oraz wykaz publikacji i tłumaczeń dotyczących literatury ormiańskiej ${ }^{16}$.

św. Grzegorza”. Zmarł 18 stycznia 1933 roku. Spoczywa na cmentarzu Łyczakowskim we Lwowie. Zob. S. Donigiewicz, Śp. Ksiądz Bogdan Dawidowicz, „Rocznik Orientalistyczny", 8, 1934, s. 201-202; K. Lewicki, Dawidowicz Bogdan, w: Polski stownik biograficzny, 4, Kraków 1938, s. 464; T. Krzyżow ski, Archidiecezja lwowska obrządku ormiańskokatolickiego w latach 1902-1938, Kraków 2020, s. 360-366.

14 S. Donigiewicz, Dzieje nauczania języka ormiańskiego, s. 37.

15 Według ankiety z 1905 roku zajęcia z języka ormiańskiego prowadzono na kilku europejskich uniwersytetach: w Berlinie, Budapeszcie, Fryburgu Bryzgowijskim, Heidelbergu, Kopenhadze, Paryżu, Strasburgu i Wiedniu. Uczestniczyły w nich kilkuosobowe grupy studentów orientalistyki lub dziedzin pokrewnych oraz teologowie, którym znajomość grabaru była potrzebna do badań w zakresie Pisma Świętego i patrologii. W Berlinie uczęszczało 3 studentów językoznawstwa porównawczego, w Budapeszcie studiowało 10 studentów, w Paryżu 3, w Kopenhadze - 4, we Fryburgu - 1. Zdarzało się też, że armeniści przekazywali wiedzę indywidualnie chętnym studentom na zasadzie doraźnych korepetycji. Wśród wykładowców wspomnieć należy kilka osób znanych i zasłużonych dla nauki. Byli to: Heinrich Hübschmann (1848-1908) - wybitny iranista i armenista, wykładowca uniwersytetu w Strasburgu, ksiądz Simon Weber (1866-1929) - teolog katolicki, profesor Nowego Testamentu na uniwersytecie we Fryburgu Bryzgowijskim, autor publikacji i tłumaczeń dotyczących Kościoła ormiańskiego, Holger Pedersen (1867-1953) - językoznawca związany z uniwersytetem w Kopenhadze. Na uniwersytetach w Oksfordzie i Cambridge także działali armeniści, ale w tym czasie

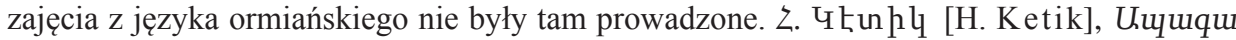
hujtiptauqkunqte [Przyszli armeniści], „Zuiqnłu Uưuoptuu]” [Handes Amsorya], 1905, 1, s. 28-32. W 1931 roku otwarto katedrę języka ormiańskiego na uniwersytecie w Brukseli. Kronika, „Posłaniec św. Grzegorza”, 5, 1931, 50, s. 120.

16 Державний архів Львівської області (dalej: DALO): f. 26, op. 7, sp. 509, k. 62-63, podanie księdza Bogdana Dawidowicza do Dziekanatu Wydziału Filozoficznego Uniwersy- 
22 lutego 1904 roku profesor Antoniewicz na spotkaniu Rady Wydziału Filozoficznego wnioskował o poparcie podania księdza Dawidowicza. Przegłosowano je większością głosów przy jednym sprzeciwie ${ }^{17}$. Równocześnie wystosowano do Ministerstwa Wyznań i Oświaty w Wiedniu obszerne pismo z prośbą o zgodę na rozpoczęcie lektoratu wraz z uzasadnieniem. Twierdzono, że wprowadzenie nowych zajęć będzie korzystne dla środowiska uniwersyteckiego, a studentom poszerzy horyzonty naukowe. Znajomość języka staroormiańskiego i poznanie klasycznej literatury uznano za nieodzowny warunek efektywnej nauki współczesnego języka ormiańskiego. Kolejnym argumentem było zapotrzebowanie ze strony lwowskiej archidiecezji ormiańskiej, której alumni na etapie formacji seminaryjnej nie mieli możliwości regularnej nauki grabaru - w obrządku ormiańskim języka liturgicznego - i byli zmuszeni wyjeżdżać na kursy do klasztoru mechitarystów w Wiedniu lub Wenecji ${ }^{18}$. Znajomość grabaru była pożądana także u studentów świeckich zainteresowanych historią i kulturą Ormian polskich. Zwrócono uwagę na to, że w zbiorach państwowych i kościelnych znajdowały się cenne źródła z zakresu szeroko pojętego dziedzictwa kulturalnego diaspory ormiańskiej na ziemiach polskich, rękopisy z wieków od XIV do XVIII, zabytki sztuki sakralnej i sepulkralnej z inskrypcjami, dotychczas niezbadane z powodu braku osób kompetentnych językowo. Wreszcie podniesiono i ten argument, że młodzież uniwersytecka ze Lwowa domaga się wprowadzenia lektoratu. Pismo zawierało także zwięzłą charakterystykę kandydata na lektora, który zdaniem sygnatariuszy petycji miał należyte wykształcenie, wiedzę i predyspozycje do prowadzenia tego typu zajęć19.

Wniosek Rady Wydziału Filozoficznego poparło Namiestnictwo Galicyjskie $^{20}$, ministerstwo odniosło się przychylnie do petycji władz fakultetu. Reskryptem z 13 kwietnia 1904 roku minister wyznań i oświaty w Wiedniu wyraził zgodę na prowadzenie lektoratu przez księdza Dawidowicza, zaznaczając, że nie będzie on miał prawa do poboru pensji uniwersyteckiej, może natomiast usta-

tetu Lwowskiego, Lwów, 15 stycznia 1904. Podanie tej samej treści złożył również w języku ormiańskim. Ibidem, k. 60-61.

${ }^{17}$ DALO: f. 26, op. 7, sp. 508, k. 36, protokół obrad Kolegium Profesorów Wydziału Filozoficznego Uniwersytetu Lwowskiego, 22 lutego 1904.

18 Archiwum Główne Akt Dawnych w Warszawie (dalej: AGAD): zespół 304, sygn. 116u, s. 380-382, pismo Rady Wydziału Filozoficznego Uniwersytetu Lwowskiego do Ministerstwa Wyznań i Oświaty (dalej: MWiO) w Wiedniu, Lwów, 22 lutego 1904.

19 Dla potwierdzenia gruntownej znajomości języka przywołano dokonane przez księdza Dawidowicza tłumaczenia z ormiańskiego na polski oraz dwa jego artykuły naukowe dotyczących historii archidiecezji lwowskiej obrządku ormiańskiego. AGAD: zespół 304, sygn. 116u, s. 376, pismo Rady Wydziału Filozoficznego Uniwersytetu Lwowskiego do MWiO w Wiedniu, Lwów, 5 marca 1904.

${ }^{20}$ AGAD: zespół 304, sygn. 116u, s. 378, pismo namiestnika Galicji Andrzeja Potockiego do MWiO, Lwów, 22 marca 1904. 
lić taksę i pobierać wynagrodzenie bezpośrednio od swoich słuchaczy ${ }^{21}$. Ksiądz Dawidowicz zrezygnował $\mathrm{z}$ takiego rozwiązania i przez szereg lat pracował bezinteresownie. Dopiero w lutym 1921 roku - już w Polsce odrodzonej - zwrócił się do dziekanatu z prośbą o przyznanie mu stosownego wynagrodzenia za wykonywaną pracę 22 . Władze Wydziału Filozoficznego podjęly starania na rzecz wyasygnowania kapłanowi stałej pensji za dwie godziny zajęć. W podaniu do ministerstwa zwrócono uwagę, że za własne środki kupował wydawnictwa naukowe niezbędne do zajęć, udostępniał je studentom i przez kilkanaście lat uczył, nie pobierając wynagrodzenia ${ }^{23}$. Starania przyniosły pożądany skutek. Ministerstwo Wyznań Religijnych i Oświecenia Publicznego w Warszawie zatwierdziło uchwałę Senatu Akademickiego odnośnie do angażu księdza Dawidowicza w wymiarze dwóch godzin lektoratu tygodniowo. Ponadto przyznało mu wynagrodzenie zgodne z artykułem 8 ustawy z 13 lipca 1920 roku $^{24}$. Pensja za trzeci trymestr roku akademickiego 1920/1921 wynosiła 4900 marek polskich i miała zostać wypłacona w trzech ratach ${ }^{25}$. W kolejnym roku akademickim wskutek gwałtownej inflacji pensja księdza Dawidowicza w pierwszym trymestrze znacznie wzrosła i wynosiła 13688 marek polskich ${ }^{26}$. Z powyższego wynika, że dopiero w roku akademickim 1920/1921 ksiądz Dawidowicz został oficjalnym pracownikiem uniwersytetu i otrzymywał stałe wynagrodzenie.

$\mathrm{Z}$ analizy programów studiów uniwersyteckich wynika, że na lektoracie prowadzonym przez księdza Dawidowicza przeważały zagadnienia z języka staroormiańskiego. Tematyka zajęć pozostawała w zasadzie niezmienna przez wiele lat, choć ulegała drobnym modyfikacjom. Zasadniczo obejmowała omówienie i praktyczne ćwiczenia $z$ gramatyki oraz lekturę i thumaczenia oryginalnych utworów klasyków literatury ormiańskiej, na przykład dzieł Mojżesza z Chorenu, zwłaszcza Historii Armenii (Tuuuñnıpjnı\{ Zujng), oraz Ewangelii Świętego Jana. Na zajęciach z języka nowoormiańskiego omawiano zagadnienia z literatury oraz czytano fragmenty twórczości Raffiego (Hakoba Melika Hakobiana) ${ }^{27}$.

${ }^{21}$ DALO: f. 26, op. 7, sp. 509, k. 58, pismo Namiestnictwa Galicyjskiego we Lwowie do Dziekanatu Wydziału Filozoficznego, Lwów, 27 kwietnia 1904.

${ }^{22}$ DALO: f. 26, op. 5, sp. 541, k. 7, pismo księdza B. Dawidowicza do Dziekanatu Wydziału Filozoficznego, Lwów, 12 lutego 1921.

${ }^{23}$ Ibidem, k. 6, pismo Rady Wydziału Filozoficznego do Senatu Akademickiego UJK, Lwów, 17 marca 1921.

${ }^{24}$ Ibidem, k. 5, pismo Ministerstwa WRiOP w Warszawie do Rektoratu UJK, Warszawa, 20 maja 1921.

${ }^{25}$ Ibidem, k. 4, kopia pisma Namiestnictwa Galicyjskiego do Krajowej Kasy Skarbowej we Lwowie, Lwów, 18 czerwca 1921.

${ }^{26}$ Ibidem, k. 10, kopia pisma Rektoratu UJK do księdza B. Dawidowicza, Lwów, 17 stycznia 1922.

27 Tytuły utworów Raffiego omawiane na zajęciach nie są znane. Można wszakże przypuszczać, że czytano fragmenty powieści Chent (ケŁ\{pp) z 1881 roku, gdyż ksiądz Dawido- 
Ksiądz Dawidowicz poruszał kwestie tak zwanego narzecza ormiańskiego w Polsce, czyli dialektu Ormian kuckich. Studenci zapoznawali się ze specyfiką rozwoju języka zachodnioormiańskiego na ziemiach polskich, gramatyką i słownictwem ${ }^{28}$. Zajęcia odbywały się zazwyczaj dwa razy w tygodniu w starym gmachu uniwersytetu przy ulicy Świętego Mikołaja 1, w godzinach wieczornych ${ }^{29}$. W 1929 roku decyzją Ministerstwa Wyznań Religijnych i Oświecenia Publicznego zwiększono liczbę godzin lektoratu do czterech tygodniowo, co wiązało się z przyznaniem lektorowi wyższego wynagrodzenia ${ }^{30}$. Po dwóch latach, w roku akademickim 1931/1932, na lektorat przeznaczono trzy godziny ${ }^{31}$. Kilkakrotnie wykłady odwoływano z różnych przyczyn: choroby lektora, działań zbrojnych podczas pierwszej wojny światowej lub braku chętnych do uczestnictwa w zajęciach. Lektoratu nie uruchomiono w latach akademickich: 1911/1912, 1913/1914, 1915/1916 (semestr letni), 1916/1917, 1917/1918, 1918/1919, 1922/1923 (trzeci trymestr), 1925/1926, 1926/1027, 1927/1928, 1928/1929, 1932/193332.

Podczas zajęć ksiądz Dawidowicz kładł nacisk na naukę grabaru i bierną znajomość języka, a więc czytanie i tłumaczenie oryginalnych tekstów. Umiejętność konwersacji spadała zapewne na dalszy plan. W przypadku zarówno przyszłych duchownych ormiańskich, jak i pasjonatów tematyki armenistycznej było to rozwiązanie korzystne i zadowalające. $Z$ kolei wykłady z języka nowoormiańskiego w jego wariancie zachodnim ksiądz Dawidowicz prowadził zaledwie przez kilka semestrów, koncentrując się na dialekcie Ormian z Kut. Wykładał również język wschodnioormiański, na co może wskazywać fakt, że czytano fragmenty utworów Raffiego, pisarza wschodniormiańskiego z Iranu. Niewykluczone, że niektóre zagadnienia językowe omawiał na zasadzie porównawczej, uwzględniając warianty wschodni i zachodni języka ormiańskiego oraz jego dialekty.

Z przeprowadzonej w 1905 roku ankiety dowiadujemy się, że ksiądz Dawidowicz przygotowywał się do zajęć z kilku podręczników i gramatyk ${ }^{33}$. Podstawę do nauki gramatyki języka ormiańskiego stanowiła praca mechitarysty wiedeńskiego Arsena Ajdyniana (1825-1902) ${ }^{34}$, choć całkiem prawdopodobne, że lek-

wicz pracował nad jej przekładem na język polski. DALO: f. 26, op. 7, sp. 509, k. 63, podanie księdza B. Dawidowicza do Dziekanatu Wydziału Filozoficznego Uniwersytetu Lwowskiego, Lwów, 15 stycznia 1904.

${ }_{28}$ Na podstawie źródeł podanych w tabeli $\mathrm{nr} 1$.

${ }^{29}$ Kronika. Lektorat języka ormiańskiego, „Posłaniec św. Grzegorza”, 4, 1930, 40-41, s. 164.

${ }^{30}$ DALO: f. 26, op. 5, sp. 541, k. 16, kopia pisma Rektoratu UJK do Dziekanatu Wydziału Humanistycznego UJK, Lwów, 2 listopada 1929.

${ }^{31}$ Ibidem, k. 28, pismo Dziekanatu Wydziału Humanistycznego UJK do Senatu Akademickiego UJK, Lwów, 13 października 1931.

${ }^{32}$ Na podstawie źródeł podanych w tabeli $\mathrm{nr} 1$.

33 z. Gtun hl, Uuququi hujteptaurqtuniten, s. 31.

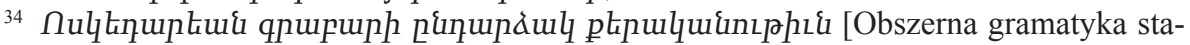
roormiańskiego języka złotego wieku], પ.łŁ氏quu [Wiedeń] 1884. 
tor sięgał również do innych jego opracowań ${ }^{35}$. Ten zasłużony mnich, filolog, tłumacz i poliglota przeszedł do historii jako autor pionierskich prac z zakresu armenistyki, zwłaszcza języka zachodnioormiańskiego. Ponadto ksiądz Dawidowicz korzystał z dzieł Juliusa Heinricha Petermanna ${ }^{36}$ - profesora filologii orientalnej w Berlinie, który między innymi udowodnił, że ormiański jest językiem indoeuropejskim, Antoine'a Meilleta ${ }^{37}$ - francuskiego językoznawcy, założyciela czasopisma „Revue des études arméniennes”, Hovhannesa Miskjiana ${ }^{38}$, Heinricha Hübschmanna ${ }^{39}$ i Carla Kainza ${ }^{40}$. Oprócz podręczników i słowników języka ormiańskiego ksiądz Dawidowicz sięgał do prac językoznawców, między innymi do publikacji wybitnego lingwisty duńskiego Holgera Pedersena ${ }^{41}$, który specjalizował się w indoeuropejskim językoznawstwie porównawczym i w tym kontekście badał również język ormiański. Ksiądz Dawidowicz czerpał informacje także z kilkutomowego dzieła z zakresu lingwistyki indoeuropejskiej dwóch wybitnych językoznawców niemieckich: Karla Brugmanna i Bertholda Delbrücka ${ }^{42}$. Wykorzystywał ponadto własne materiały, które sukcesywnie gromadził w trakcie studiów nad językiem ormiańskim, zwłaszcza dialektem Ormian polskich.

Ucząc na uniwersytecie lwowskim, ksiądz Dawidowicz zorientował się, że motywy osób decydujących się na uczestnictwo w lektoracie były zróżnicowane. Niektórzy studenci chcieli poszerzyć horyzonty językowe, a inni planowali zdobyć praktyczne umiejętności czytania i wymowy niezbędne do korzystania z ksiąg liturgicznych w obrządku ormiańskim. Stąd uznał za konieczne uruchomienie drugiego, równoległego kursu i podział studentów na kurs początkowy

${ }^{35}$ Ważna w badaniach nad językiem ormiańskim była również jego praca: $q$ qquuluu氏

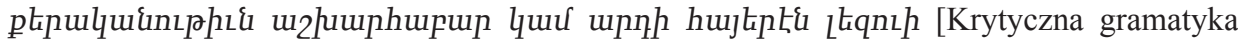
świeckiego, czyli współczesnego języka ormiańskiego], પ.,łłq\{uu [Wiedeń] 1866. Wspólnie z mechitarystą Wyrtanesem Czałychianem (Чppuqutu 2ußnłukuqu) opracował także:

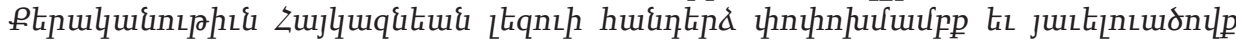
[Gramatyka języka narodu ormiańskiego wraz ze zmianami i uzupełnieniami], Ч.hłદ氏quu [Wiedeń] 1885.

${ }^{36}$ J. H. Petermann, Brevis linguae armeniacae. Grammatica, litteratura, chrestomathia cum glossario. In usum praelectionum et studiorum privatorum, Berolini 1872.

37 A. Meillet, Esquisse d'une grammaire comparée de l'arménien classique, Vienne 1903.

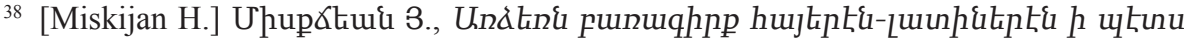
nupnguig (Manuale lexicon Armeno-Latinum. Ad usum scholarum), Znnu [Rzym] 1887.

${ }_{39}$ H. Hübschmann, Armenische Studien, Leipzig 1883; id em, Armenische Grammatik, Leipzig 1895.

${ }^{40}$ C. Kainz, Praktische Grammatik der armenischen Sprache für den Selbstunterricht, 1, Classische Sprache, 2, Neu-armenische Sprache mit einem neu-armenisch-deutschen und deutsch-neu-armenischen Wörterbuch und zahlreichen Lesestücken, Wien 1891.

${ }^{41}$ Wydał m.in.: Zur armenischen Sprachgeschichte, „Zeitschrift für vergleichende Sprachforschung", 38, 1902, s. 194-240; Armenisch und die Nachbarsprachen, ibidem, 39, 1904, s. 334-485.

${ }^{42}$ K. Brugmann, B. Delbrück, Grundriß der vergleichenden Grammatik der indogermanischen Sprachen, Strassburg 1886-1900. 
i zaawansowany ${ }^{43}$. Statystyk słuchaczy lektoratu nie prowadzono, dlatego nie jest możliwe odtworzenie pełnego składu uczestników. Była to kameralna grupa składająca się z kilku osób, przeważnie kleryków archidiecezji ormiańskiej"${ }^{44}$, orientalistów, językoznawców lub sympatyków tematyki ormiańskiej ${ }^{45}$. W roku akademickim 1904/1905 na zajęcia uczęszczali: Kajetan Amirowicz i Jakub Axentowicz - klerycy ormiańscy, księża Andrzej Łukasiewicz i Edward Tomaszewski - wikariusze katedralni, ksiądz Karol Bogdanowicz - kanonik kapituły ormiańskiej, student Jakub Moszoro z Wydziału Prawa oraz dwaj studenci językoznawstwa: Andrzej Gawroński i Jan Pilczar ${ }^{46}$. W kolejnych latach w lektoracie brali udział w różnym czasie i z różną częstotliwością również: Bohdan Janusz - lwowski konserwator zabytków i autor prac dotyczących historii Ormian polskich, profesor Roman Barącz - chirurg, poliglota i kolekcjoner, Stanisław Donigiewicz - urzędnik, zaangażowany w działalność środowiska ormiańskiego, Mikołaj Mojzesowicz - student politechniki, znawca zwyczajów Ormian w Kutach i autor artykułów z tej tematyki, Krzysztof Donigiewicz - student Akademii Medycyny Weterynaryjnej we Lwowie i działacz ormiański, Zbigniew Bober student polonistyki Uniwersytetu Jana Kazimierza, Dominik Janowicz - student, członek i założyciel Archidiecezjalnego Związku Ormian, Franciszek Zachariasiewicz - członek zarządu Archidiecezjalnego Związku Ormian i komitetu redakcyjnego „Posłańca św. Grzegorza” oraz profesor Jakub Bohosiewicz, Kaje$\tan$ Zachariasiewicz i Stanisław Zachariasiewicz ${ }^{47}$. Wymienieni oprócz Andrzeja Gawrońskiego, Jana Pilczara, księdza Edwarda Tomaszewskiego i Bohdana Janusza wywodzili się z rodzin ormiańskich. Ośmiu z nich włączyło się w powstanie i działalność Archidiecezjalnego Związku Ormian we Lwowie zorganizowanego w 1930 roku. Można więc śmiało rzec, że lektorat oprócz edukacji językowej spełniał funkcję integracyjną środowiska ormiańskiego.

Grupa uczęszczających na lektorat była zróżnicowana zarówno pod względem wieku, studiów kierunkowych, które odbywali lub ukończyli, jak i wykonywanej profesji. Lektorat prowadzony był jako przedmiot nadobowiązkowy,

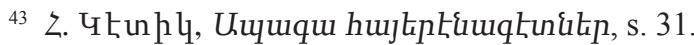

${ }^{44}$ Zakładając, że wszyscy klerycy obrządku ormiańskiego studiujący na Wydziale Teologicznym we Lwowie i wyświęceni na kapłanów w latach 1904-1939 uczęszczali na lektorat, można stwierdzić, że było ich 13. T. Krzyżowski, Archidiecezja lwowska, s. 294. Wykaz uwzględnia także kleryków, którzy studiowali po śmierci księdza Dawidowicza, kiedy lektorem był Garabed Keuprulian (zob. niżej). Dane nie obejmują alumnów, którzy przerwali formację seminaryjną i nie przyjęli święceń kapłańskich.

45 DALO: f. 26, op. 15, sp. 1007, k. 43, karta wpisowa na wykłady w Uniwersytecie Lwowskim, Lwów, 1906/1907.

${ }^{46}$ Catalogus universi cleri et schematismus archidioecesis Leopoliensis ritus armeno-

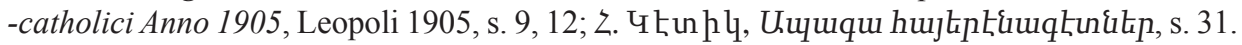

${ }^{47}$ Figurują oni na fotografii uczestników lektoratu księdza Donigiewicza zachowanej w zbiorach Fundacji Kultury i Dziedzictwa Ormian Polskich w Warszawie. 
dlatego przychodzili też wolni słuchacze. Wieczorna pora zajęć sprzyjała zaangażowaniu osób, które w ciągu dnia miały zobowiązania zawodowe.

Trudno scharakteryzować efekty nauki. Andrzej Gawroński, późniejszy profesor Uniwersytetu Lwowskiego, opanował klasyczny język ormiański i nowoormiański, lecz naukę rozpoczął wcześniej i kontynuował również poza Lwowem $^{48}$. Ksiądz Kajetan Amirowicz podobnie, gdyż po opanowaniu podstaw grabaru został wysłany przez przełożonych na kurs zaawansowany do Papieskiego Kolegium Ormiańskiego w Rzymie ${ }^{49}$. Wiadomo, że językiem ormiańskim władał biegle profesor Roman Barącz. Był to efekt wieloletniej wytężonej pracy oraz zdolności i pasji do nauki języków obcych ${ }^{50}$. Język ormiański, a przynajmniej jego podstawy, znali Stanisław Donigiewicz i Mikołaj Mojzesowicz oraz księża ormiańscy, którzy podczas swojej formacji i studiów na Wydziale Teologicznym brali udział w lektoracie. Efektywną naukę języka ormiańskiego utrudniał brak podręcznika w języku polskim; osoby zainteresowane musiały sięgać do wydań zagranicznych, głównie niemieckojęzycznych. $\mathrm{Z}$ adnotacji profesora Gawrońskiego na jednym z dokumentów wynika, że nie zawsze znajdowali się chętni do nauki języka ormiańskiego ${ }^{51}$. W niektórych latach akademickich we lwowskiej archidiecezji ormiańskiej nie było kleryków bądź podejmowali oni edukację poza Lwowem ${ }^{52}$.

Po śmierci księdza Dawidowicza, w maju 1933 roku, prośbę do Rady Wydziału Humanistycznego o powierzenie mu lektoratu języka ormiańskiego ${ }^{53}$ wniósł Garabed Keuprulian $^{54}$. Rada zaakceptowała petycję, a 30 czerwca 1933 roku

48 Język ormiański zaczął studiować w wieku 14 lat. Dzięki znajomości jego rodziny z mechitarystami z San Lazzaro często bywał w klasztornej bibliotece i studiował dzieła literatury ormiańskiej. Przyjaźń nawiązaną z zakonnikami utrzymywał przez całe życie. Znał język staroormiański oraz języki nowoormiańskie w wersji wschodniej i zachodniej. W swojej bibliotece zgromadził wiele książek i słowników języka ormiańskiego. E. Słuszkiewicz, Wspomnienie o Andrzeju Gawrońskim. W dziesięciolecie zgonu, „Rocznik Orientalistyczny”, 1936, 12, s. 218; idem, Andrzej Gawroński (w czterdziestolecie zgonu), w: Szkice z dziejów polskiej orientalistyki, red. J. Rey chman, Warszawa 1966, s. 175; Z. Kozarynow a, Andrzej Gawroński (1885-1927), „Znak”, 34, 1982, 6, s. 583, 585.

49 T. Krzyżow ski, Archidiecezja lwowska, s. 286.

50 S. Donigiewicz, Śp. Prof. dr Roman Baracz, „Posłaniec św. Grzegorza”, 5, 1931, 44, s. 6 .

${ }^{51}$ DALO: f. 26, op. 5, sp. 541, k. 7, adnotacja profesora Andrzeja Gawrońskiego [Lwów, luty 1921].

${ }^{52}$ Ibidem, k. 13, kopia pisma Dziekanatu Wydziału Humanistycznego do księdza B. Dawidowicza, Lwów, 6 grudnia 1928, k. 13.

${ }^{53}$ DALO: f. 26, op. 5, sp. 841, k. 2, podanie Garabeda Keupruliana do Rady Wydziału Humanistycznego UJK, Lwów, 31 maja 1933.

${ }^{54}$ Garabed Keuprulian urodził się 29 marca 1884 roku w Adrianopolu (Turcja). W 1903 roku ukończył tamtejsze gimnazjum bułgarskie prowadzone przez księży zmartwychwstańców. W wyniku prześladowań ze strony Turków przyjechał do Lwowa, gdzie na politechnice 
Senat Akademicki uchwalił prowadzenie lektoratu przez Keupruliana w liczbie trzech godzin tygodniowo ${ }^{55}$. Zajęcia odbywały się w Instytucie Orientalistycznym przy ulicy Kościuszki 9 od listopada 1933 roku. Po upływie niespełna dwóch miesięcy zostały jednak przerwane na sześć tygodni z powodu złamania ręki przez Keupruliana, który poddany został hospitalizacji ${ }^{56}$. Zaległe zajęcia za październik i połowę listopada miały zostać odpracowane w trzecim trymestrze ${ }^{57}$. W kolejnym roku akademickim (1934/1935) lektorat rozpoczął się z opóźnieniem z powodu komplikacji zdrowotnych lektora, który w październiku przebywał na leczeniu w sanatorium. Wprawdzie zajęcia miały się rozpocząć pod koniec października, ale czy do tego doszło, nie wiadomo, gdyż dolegliwości zdrowotne Keupruliana spowodowane złamaniem ramienia oraz zwichnięciem nogi nasiliły się i musiał on kontynuować rehabilitację ${ }^{58}$. W związku z tym wniósł podanie o udzielenie urlopu w pierwszym trymestrze roku akademickiego 1934/1935. Na swojego zastępcę zaproponował księdza Bohosa Kirmizjana, pracującego od lat we Lwowie, podkreślając jego wysokie kompetencje jako znawcy grabaru i współczesnego języka ormiańskiego. Angaż księdza Kirmizjana nie doszedł wszakże do skutku, gdyż Keuprulian wycofał rezygnację, z czego należy

uzyskał tytuł inżyniera. Przez wiele lat pracował w Wydziale III Urzędu Miejskiego we Lwowie, między innymi jako kierownik betoniarni. W 1935 roku z powodu problemów zdrowotnych przeszedł na emeryturę. 16 listopada 1929 roku zawarł w katedrze ormiańskiej we Lwowie powtórny związek małżeński z muzykolożką Bronisławą Wójcik (1890-1938). Wraz z żoną angażował się w działalność Archidiecezjalnego Związku Ormian we Lwowie oraz redagowanie czasopisma „Posłaniec św. Grzegorza”. Przetłumaczył na język francuski przewodnik po katedrze ormiańskiej autorstwa księdza Dionizego Kajetanowicza (La cathédrale arménienne de Lwów et son entourage. Guide, Lwów 1931). W 1934 roku wyjechał do Warszawy, gdzie od następnego roku prowadził lektorat języka ormiańskiego na Uniwersytecie Warszawskim. W tym samym roku starał się o posadę lektora języka bułgarskiego na Uniwersytecie Jana Kazimierza. Władze Zakładu Filologii Słowiańskiej odmówiły mu jej, twierdząc, że chcą zaangażować na to stanowisko ,rodowitego Bułgara”. Zmarł 14 maja 1939 roku we Lwowie. DALO: f. 26, op. 5, sp. 841, teczka personalna Garabeda Keupruliana; Sprawozdanie z działalności Wydziału Humanistycznego Uniwersytetu J. Pitsudskiego za rok akad[emicki] 1935-1936, Warszawa 1937, s. 13; Drugi lektorat języka ormiańskiego w Polsce, „Gregoriana”, 1936, 3-4, s. 157; Z kroniki żałobnej. Śp. inż. Garabed Keuprulian, „Posłaniec św. Grzegorza", 13, 1939, 3, s. 130-131; B. Wójcik-Keuprulian, Korespondencja do Szwajcarii. Listy do Henryka Opieńskiego (1925-37) i Ludwika Bronarskiego (1929-38), oprac.

M. Sieradz, Warszawa 2018, s. 24-28.

55 DALO: f. 26, op. 5, sp. 841, k. 3, pismo Rektoratu UJK do G. Keupruliana, Lwów, 9 listopada 1933.

${ }^{56}$ Ibidem, k. 6, pismo B. Wójcik-Keuprulian do Dziekanatu Wydziału Humanistycznego UJK, Lwów, 15 stycznia 1934.

${ }^{57}$ Ibidem, k. 8, pismo G. Keupruliana do Dziekanatu Wydziału Humanistycznego UJK, Lwów, 9 marca 1934.

${ }^{58}$ Ibidem, k. 9, pismo G. Keupruliana do Dziekanatu Wydziału Humanistycznego UJK, Lwów, 20 października 1934, k. 10; pismo tegoż do tegoż, Lwów, 29 października 1934. 
wnioskować, że wrócił do pracy ${ }^{59}$. Lektorat prowadzono przez trzy godziny tygodniowo w każdym z trymestrów ${ }^{60}$.

We wrześniu 1936 roku do rektora Uniwersytetu Jana Kazimierza, profesora Jana Czekanowskiego, zwrócił się arcybiskup ormiański Józef Teodorowicz z propozycją personalną dotyczącą obsadzenia lektoratu języka ormiańskiego po ewentualnym ustąpieniu Keupruliana. Z listu wynika, że sprawa była omawiana już wcześniej i to Czekanowski pierwszy zasięgał opinii arcybiskupa. Teodorowicz polecał na to stanowisko księdza Kazimierza Romaszkana, absolwenta Papieskiego Kolegium Ormiańskiego w Rzymie. Pisał: „Przewyższa on i znajomością i opanowaniem języka ormiańskiego nieporównanie ustępującego lektora $\mathrm{p}$ [ana] Keupruliana; włada on w piśmie i słowie tym językiem jak rodzimym, a nadto co jest najważniejsze, posiada on znajomość liturgicznego języka ormiańskiego na czym niestety zbywało $\mathrm{p}$ [anu] Keuprulianowi” ${ }^{61}$. Twierdził też, że ksiądz Romaszkan zachęci młodzież akademicką do uczestniczenia w lektoracie $^{62}$. Swoją opinię wyraził w tej sprawie profesor Jerzy Kuryłowicz, któremu podlegał lektorat języka ormiańskiego. Wyjaśnił, że Keuprulian został zatwierdzony jako lektor przez Ministerstwo Wyznań Religijnych i Oświecenia Publicznego na cały rok akademicki. Ponadto ponownie zamieszkał na stałe we Lwowie, co unieważniło jedyny zarzut, jaki kierowano pod jego adresem ${ }^{63}$. Z tego powodu propozycja arcybiskupa Teodorowicza nie została przyjęta ${ }^{64}$. Co ciekawe, kiedy rok później Keuprulian poprosił o urlop i zrezygnował z prowadzenia zajęć w roku akademickim 1937/1938, nie szukano dla niego zastępcy, ale pozostałe godziny przeznaczono na dodatkowe zajęcia z języka angielskiego ${ }^{65}$. Po roku Keuprulian wrócił na uczelnię. Ostatnie zajęcia prowadził w roku akademickim 1938/1939. Za trzy godziny tygodniowo zajęć otrzymywał 105 złotych miesięcznej pensji ${ }^{66}$. W 1938 roku zajęcia odbywały się w poniedziałki, środy i piątki od godziny 17 do 18 w Instytucie Orientalistycznym przy ulicy Kościuszki $9^{67}$.

${ }^{59}$ Ibidem, k. 11, pismo tegoż do tegoż, Lwów, 30 listopada 1934.

${ }^{60}$ Ibidem: f. 26, op. 7, sp. 1365, k. 77, lektoraty w roku akademickim 1934/35.

${ }^{61}$ Archiwum Fundacji Kultury i Dziedzictwa Ormian Polskich w Warszawie, Spuścizna arcybiskupa Józefa Teodorowicza, t. 128, sygn. 835/110 [5], s. 3-4, kopia listu arcybiskupa J. Teodorowicza do profesora Jana Czekanowskiego, Lwów, 8 września 1936.

${ }^{62}$ Ibidem, s. 4.

${ }^{63}$ DALO: f. 26, op. 5, sp. 841, k. 17, pismo profesora Jerzego Kuryłowicza do Rektoratu UJK, Lwów, 13 października 1936.

${ }^{64}$ Ibidem, k. 19, brudnopis pisma Rektoratu UJK do arcybiskupa J. Teodorowicza, Lwów, 20 października 1936.

${ }^{65}$ Ibidem, k. 20, kopia pisma dziekanatu Wydziału Humanistycznego do MWRiOP w Warszawie, Lwów, 15 października 1937.

${ }^{66}$ Ibidem, k. 32, umowa o pracę zawarta z G. Keuprulianem, Lwów, 24 października 1938.

${ }^{67}$ Lektorat języka ormiańskiego na U[niwersytecie] J[ana] K[azimierza], „Gregoriana”, 1938, 4, s. 274. 
Zagadnienia poruszane na lektoracie Keupruliana nie są znane. W dokumentacji archiwalnej występuje on jako lektor języka staro- i nowoormiańskiego, w programach wykładów nazwa przedmiotu brzmi: ,język ormiański”. Prawdopodobnie prowadził zajęcia ze współczesnego języka zachodnioormiańskiego.

Oprócz wspomnianych lektoratów w okresie międzywojennym odbywały się wykłady z języka ormiańskiego, prowadzone przez profesorów Instytutu Orientalistycznego. Wykłady z klasycznego języka ormiańskiego i literatury staroormiańskiej prowadził w latach akademickich 1921/1922-1924/1925 wybitny językoznawca i multilingwista profesor Andrzej Gawroński ${ }^{68}$. Znany z wysokich wymagań postawił warunek, aby studenci zapisujący się na zajęcia ze staroormiańskiego znali dobrze łacinę i grekę. Osobny wykład poświęcił analizie dzieła Eznika z Koghb, piszącego w V wieku, pod tytułem Obalenie herezji (†nd unuinng), uważanego za jeden z najważniejszych utworów w języku staroormiańskim. Od roku akademickiego 1925/1926 Gawroński zrezygnował z zajęć armenistycznych i prowadził wykłady z filologii irańskiej i indyjskiej. Przez dekadę tematyce języka ormiańskiego nie poświęcano w Instytucie Orientalistycznym osobnych zajęć. Dopiero w roku akademickim 1935/1936 i 1938/1939 profesor Kuryłowicz ${ }^{69}$

${ }^{68}$ Andrzej Gawroński urodził się 20 czerwca 1885 roku w Genewie. Edukację gimnazjalną odbył w Przemyślu i Lwowie. Studiował na Wydziale Filozoficznym Uniwersytetu Lwowskiego (1903-1905), następnie kontynuował studia językoznawcze i indologiczne na Uniwersytecie w Lipsku, gdzie w 1907 roku obronił doktorat z sanskrytu. W 1912 roku habilitował się na Uniwersytecie Jagiellońskim z filologii indyjskiej. Od 1913 roku wykładał na Uniwersytecie Jagiellońskim, gdzie w 1916 roku został mianowany profesorem nadzwyczajnym filologii staroindyjskiej. W 1917 roku został profesorem nadzwyczajnym gramatyki porównawczej języków indoeuropejskich i sanskrytu na Uniwersytecie Lwowskim, a w 1920 roku - profesorem zwyczajnym tamże. Był członkiem korespondentem, a następnie członkiem rzeczywistym Polskiej Akademii Umiejętności. Przyczynił się do zorganizowania Instytutu Orientalistycznego we Lwowie i Polskiego Towarzystwa Orientalistycznego (1923). Był redaktorem „Rocznika Orientalistycznego”. Zajmował się naukowo indianistyką, zwłaszcza sanskrytem, w swych publikacjach poruszał też zagadnienia filozoficzne i historyczne Indii, opracował podręcznik sanskrytu, tłumaczył literaturę i poezję, między innymi z języka perskiego i węgierskiego; podejmował zagadnienia językoznawcze z języka polskiego. Miał bardzo szerokie zainteresowania badawcze, nieprzeciętne zdolności i pamięć fotograficzną, która umożliwiała mu zapamiętywanie znacznych fragmentów tekstu w różnych językach, jednak dorobek naukowy, który pozostawił, jest nieproporcjonalny do jego wiedzy. Zmarł na gruźlicę 11 stycznia 1927 roku. DALO: f. 26, op. 7, sp. 809, k. 85, życiorys profesora A. Gawrońskiego, Lwów, 29 maja 1921; f. 26, op. 5, sp. 334, k. 69, życiorys profesora A. Gawrońskiego, Lwów, 1927; K. Nitsch, Gawroński Andrzej (1885-1927), w: Polski słownik biograficzny, 7, Kraków 1948-1958, s. 325-328; E. Słuszkiewicz, Andrzej Gawroński, s. 174-176.

${ }^{69}$ Jerzy Kuryłowicz urodził się 26 sierpnia 1895 roku w Stanisławowie, ukończył gimnazjum klasyczne we Lwowie (1913), studiował w Hochschule für Welthandel w Wiedniu (1913-1914, 1918-1920), Szkole Języków Wschodnich tamże (1918-1920), a także romanistykę i germanistykę na UJK (1920-1923) oraz w École des Hautes Études w Paryżu (19231925), gdzie uczęszczał na wykłady między innymi Antoine’a Meilleta. W 1923 roku obronił 
podjął wykłady z języka staroormiańskiego w ujęciu historyczno-porównawczym $^{70}$.

Najdłużej zajęcia z języka ormiańskiego prowadził ksiądz Bogdan Dawidowicz, który wykładał z przerwami przez 29 lat. Oferta edukacyjna na Uniwersytecie Jana Kazimierza dla osób zainteresowanych tematyką ormiańską rozszerzyła się w latach 1921/1922-1924/1925 oraz 1935/1936 i 1938/1939, kiedy równolegle do lektoratu odbywały się zajęcia profesorów Gawrońskiego i Kuryłowicza. Na nie uczęszczali przeważnie orientaliści i językoznawcy, praktyczniejszy wymiar miał lektorat, skierowany do szerszego grona odbiorców.

Warto tu jeszcze wspomnieć o koncepcji lwowskiego konserwatora i badacza dziejów Ormian polskich Bogdana Janusza, który w latach 20. ubiegłego stulecia postulował powołanie instytutu armenistycznego. Naczelnym zadaniem tej instytucji miało być przekształcenie lektoratu języka ormiańskiego w katedrę armenistyki ${ }^{71}$. Temat utworzenia katedry pojawia się także we wspomnieniach o profesorze Andrzeju Gawrońskim, który chciał nią pokierować, co żartobliwie uzasadniał: „Wtedy będę miał jednego słuchacza na pięć lat i będę mógł spokojnie pracować"72. Planował w niej zająć się badaniami nad dialektem Ormian kuckich ${ }^{73}$. Biorąc pod uwagę ówczesne uwarunkowania natury organizacyjnej i ekonomicznej oraz niewielką liczbę osób deklarujących zainteresowanie armenistyką, powołanie osobnej katedry języka ormiańskiego było mało realne.

W dwudziestoleciu międzywojennym środowisko lwowskie podejmowało też przedsięwzięcia badawcze w zakresie armenistyki. Profesor Gawroński i ksiądz

doktorat z romanistyki na UJK, w 1926 roku uzyskał habilitację z językoznawstwa indoeuropejskiego tamże, w 1928 roku został profesorem nadzwyczajnym językoznawstwa indoeuropejskiego, a w 1934 roku - profesorem zwyczajnym. Działał jako radny Lwowa (od 1939). Był ostatnim dziekanem Wydziału Humanistycznego UJK (od 1939). Po drugiej wojnie światowej kierował Katedrą Językoznawstwa Ogólnego na Uniwersytecie Wrocławskim (1946-1948) oraz analogiczną katedrą na Uniwersytecie Jagiellońskim (1948-1965). Od 1931 roku był członkiem korespondentem Polskiej Akademii Umiejętności, od 1938 - członkiem rzeczywistym, a od 1952 roku członkiem rzeczywistym PAN. Zajmował się językoznawstwem indoeuropejskim i diachronicznym, był autorem pionierskich prac, poliglotą, pozostawił po sobie bogaty dorobek naukowy. Zmarł 28 stycznia 1978 roku w Krakowie. DALO: f. 26, op. 5, sp. 1023, teczka personalna profesora Jerzego Kuryłowicza; A. Heinz, Profesor Jerzy Kuryłowicz. Wspomnienie pośmiertne, „Biuletyn Polskiego Towarzystwa Językoznawczego", 37, 1980, s. 3-7.

${ }^{70}$ Na podstawie źródeł podanych w tabeli nr 1.

71 B. Janusz, O potrzebie założenia we Lwowie „Ormiańskiego Muzeum Diecezjalnego”, w: Pamiętnik V. Zjazdu Delegatów Związu Muzeów w Polsce odbytego w Tarnowie w dn[iach] 12-13 czerwca 1930, red. M. Piotrowski, Kraków 1930, s. 41.

${ }^{72}$ Cyt. za: E. Słuszkiewicz, Andrzej Gawroński, s. 175.

${ }^{73}$ Śp. Andrzej Gawroński, „Rocznik Orientalistyczny”, 1926 [wyd. 1928], 4, s. V; K. Nitsch, Andrzej Gawroński, „Przegląd Współczesny”, 6, 1927, 58, s. 191. 
Dawidowicz prowadzili badania nad dialektem Ormian w Kutach. Ich wyniki miały zostać ogłoszone drukiem nakładem Polskiej Akademii Umiejętności ${ }^{74}$. Maszynopis rozprawy zaginął w niewyjaśnionych okolicznościach lub w ogóle nie powstał, gdyż współpraca obu uczonych została przerwana przez śmierć Gawrońskiego w 1927 roku. Gawroński temat języka ormiańskiego podejmował również samodzielnie ${ }^{75}$, chociaż armenistyka nie była wiodącym kierunkiem jego dociekań naukowych. Ksiądz Dawidowicz nie pozostawił po sobie żadnych prac z zakresu filologii orientalnej. Dialektem Ormian kuckich interesował się potem profesor Kuryłowicz. W 1931 roku wziął miesięczny urlop naukowy i udał się do Kut w celu zebrania materiału źródłowego. Jego badania wsparło Ministerstwo Wyznań Religijnych i Oświecenia Publicznego ${ }^{76}$. Nie opublikował jednak ich wyników ${ }^{77}$.

Badania w zakresie języka i literatury ormiańskiej prowadził przed drugą wojną światową we Lwowie również Eugeniusz Słuszkiewicz, uczeń profesora Andrzeja Gawrońskiego i pracownik Uniwersytetu Jana Kazimierza ${ }^{78}$.

Dostrzeżono też wówczas potrzebę opracowania gramatyki i słownika języka ormiańskiego zawierającego zestaw najbardziej podstawowego i przydatnego słownictwa. W 1929 roku Stanisław Donigiewicz upublicznił w formie powielonego rękopisu Gramatykę języka ormiańskiego ${ }^{79}$. Były to jego notatki z zajęć uniwersyteckich, rozszerzone i uzupełnione pod nadzorem księdza Dawidowicza. Zawierały podstawowe informacje niezbędne do nauki: historię powstania języka i jego rozwoju, alfabet, zasady gramatyki, części mowy, deklinacje, odmianę i stopniowanie przymiotników, informacje o liczebnikach, zaimkach, podstawowe słownictwo i tym podobne. Ponadto podał najważniejsze zasady wymowy. Gramatyka miała się składać z 12 zeszytów i można ją było nabyć za 6 złotych

74 S. Donigiewicz, Śp. Ksiądz Bogdan Dawidowicz, s. 202.

75 Wydał: Język Ormian polskich, w: Język polski i jego historia z uwzględnieniem innych języków na ziemiach polskich, 2, red. H. Ułaszyn et al., Kraków 1915, s. 452-455. Gawroński planował opracowanie także innych zagadnień dotyczących języka ormiańskiego i dziejów ormiańskich, czemu na przeszkodzie stanęła jego przedwczesna śmierć. E. Słuszkiewicz, Wspomnienie o Andrzeju Gawrońskim, s. 227-228.

${ }^{76}$ DALO: f. 26, op. 5, sp. 1023, k. 123, pismo profesora J. Kuryłowicza do Rektoratu UJK, Lwów, 7 stycznia 1931; k. 120, pismo Rektoratu UJK do profesora J. Kuryłowicza, Lwów, 8 stycznia 1931.

77 A. Pisowicz, Znajomość języka i literatury ormiańskiej w Polsce w XIX i XX wieku, „Przegląd Orientalistyczny”, 1999, 3-4, s. 189.

78 Szerzej na temat jego aktywności naukowej w dziedzinie armenistyki zob. E. Tryjarski, Eugeniusz Stuszkiewicz - najwybitniejszy armenista polski (1901-1981), „Przegląd Orientalistyczny”, 1983, 1-4, s. 11-19; Bibliografia prac prof. dra Eugeniusza Stuszkiewicza (1927-1973), oprac. A. i E. Ługowscy, w: Księga pamiątkowa ku czci Eugeniusza Stuszkiewicza, red. J. Reychman, Warszawa 1974, s. 9-19.

79 S. Donigiewicz, Gramatyka języka ormiańskiego, 1, Język staroormiański, Lwów 1929 (reprint: Gliwice 1973); powielany rękopis. 
bezpośrednio u autora ${ }^{80}$. Była jedynym opracowaniem tego typu w języku polskim. Nie udało się ustalić, czy poza zeszytem pierwszym Donigiewicz opracował i udostępnił kolejne.

Z kolei ksiądz Kirmizjan przez wiele lat zbierał materiały do słownika ormiańsko-francuskiego, który według informacji Keupruliana z 1934 roku był na ukończeniu i miał się ukazać nakładem wydawnictwa mechitarystów w Wenecji ${ }^{81}$. Przez kilkanaście lat ksiądz Kirmizjan gromadził również materiał do słownika ormiańsko-polskiego. Szacunkowa objętość planowanej edycji miała wynosić około dwóch tysięcy stron niewielkiego formatu ${ }^{82}$. Powyższe słowniki nigdy nie ukazały się drukiem.

Kolejnym niesfinalizowanym przedsięwzięciem był podręcznik do nauki języka ormiańskiego wraz z gramatyką i słownikiem autorstwa Garabeda Keupruliana. Pod koniec 1938 roku na łamach „Posłańca św. Grzegorza” zamieszczono informację, że podręcznik taki, liczący czterysta stron, ze wstępem dotyczącym dziejów Armenii i Ormian polskich autorstwa Bronisławy Wójcik-Keuprulian, skierowany został do druku i wkrótce dostępny będzie w sprzedaży. Cena książki miała wynosić 4 złote, a redakcja periodyku zachęcała do składania zamówieńn ${ }^{83}$. Przypuszczalnie druk został wstrzymany przez zgon autora, problemy natury finansowej lub inne, nieznane obecnie czynniki.

$\mathrm{W}$ omawianym okresie (schyłkowe lata istnienia monarchii austro-węgierskiej oraz dwudziestolecia międzywojennego) zainteresowanie językiem ormiańskim w środowisku lwowskim wzrosło. Przekładało się to na przedsięwzięcia natury naukowej, edukacyjnej, wydawniczej i kulturalnej, od strony społecznej wspierane w latach 30. przez Archidiecezjalny Związek Ormian. Uruchomienie lektoratu języka ormiańskiego było celnym posunięciem władz lwowskiej uczelni, wzbogaciło ofertę językową i umożliwiło naukę klerykom archidiecezji ormiańskiej, studentom różnych kierunków i wolnym słuchaczom. Lektorat i wykłady z języka ormiańskiego wpisują się także w szerszy kontekst rozwoju lwowskiej orientalistyki. Na Uniwersytecie Jana Kazimierza miała ona swój najsilniejszy ośrodek w Polsce, w którym wykładali cenieni specjaliści, realizowano inicjatywy naukowe i wydawnicze.

${ }^{80}$ Gramatyka języka ormiańskiego, „Posłaniec św. Grzegorza”, 3, 1929, 31, s. 176; Z piśmiennictwa. Gramatyka języka ormiańskiego, 1, Język staroormiański, „Posłaniec św. Grzegorza”, 4, 1930, 32-33, s. 20; Z piśmiennictwa. Gramatyka języka ormiańskiego, „Posłaniec św. Grzegorza", 4, 1930, 36-37, s. 103.

${ }^{81}$ DALO: f. 26, op. 5, sp. 841, k. 12, życiorys księdza Pawła Kirmizjana [Lwów 1934].

82 Ibidem; Słownik ormiańsko-polski, „Posłaniec św. Grzegorza”, 12, 1938, 4, s. 82.

83 Z życia naszego Związku, „Posłaniec św. Grzegorza”, 12, 1938, 4, s. 83. 
Tabela 1. Zajęcia z języka ormiańskiego na Uniwersytecie Lwowskim w latach 1904-1939

\begin{tabular}{|c|c|c|c|c|}
\hline Lp. & $\begin{array}{l}\text { Wykładowca/ } \\
\text { lektor }\end{array}$ & Rodzaj zajęć & Rok akademicki & $\begin{array}{l}\text { Liczba go- } \\
\text { dzin tygo- } \\
\text { dniowo }\end{array}$ \\
\hline \multirow[t]{5}{*}{1.} & \multirow[t]{5}{*}{$\begin{array}{l}\text { Bogdan } \\
\text { Dawidowicz }\end{array}$} & \multirow[t]{3}{*}{ język staroormiański } & $\begin{array}{l}1904 / 1905 \\
1906 / 1907 \\
1907 / 1908 \\
1908 / 1909 \\
1909 / 1910 \\
1910 / 1911 \\
1912 / 1913 \\
1914 / 1915 \\
1915 / 1916, \text { sem. I } \\
1919 / 1920 \\
1920 / 1921 \\
1921 / 1922, \text { trym. I i II }\end{array}$ & 2 \\
\hline & & & \begin{tabular}{|l|}
$1929 / 1930$ \\
$1930 / 1931$ \\
\end{tabular} & 4 \\
\hline & & & $1931 / 32$ & 3 \\
\hline & & język nowoormiański & $\begin{array}{l}1905 / 1906 \\
1923 / 1924 \\
1924 / 1925\end{array}$ & 2 \\
\hline & & $\begin{array}{l}\text { język nowoormiański, } \\
\text { dialekt Ormian kuckich }\end{array}$ & $\begin{array}{l}1921 / 1922, \text { trym. III } \\
\text { 1922/1923, trym. I i II }\end{array}$ & 2 \\
\hline \multirow[t]{5}{*}{2.} & \multirow[t]{5}{*}{ Andrzej Gawroński } & $\begin{array}{l}\text { język ormiański } \\
\text { klasyczny dla } \\
\text { początkujących }\end{array}$ & $1921 / 1922$ & 2 \\
\hline & & \multirow[t]{2}{*}{ lektura staroormiańska } & $1921 / 1922$ & 2 \\
\hline & & & 1922/1923 & 1 \\
\hline & & język ormiański & \begin{tabular}{|l|}
$1923 / 1924$ \\
$1924 / 1925$ \\
\end{tabular} & 1 \\
\hline & & język staroormiański & $1924 / 1925$ & 2 \\
\hline \multirow[t]{3}{*}{3.} & \multirow[t]{3}{*}{$\begin{array}{l}\text { Garabed } \\
\text { Keuprulian }\end{array}$} & języka ormiańskiego & \begin{tabular}{|l|}
$1933 / 1934$ \\
$1935 / 1936$ \\
$1936 / 1937$ \\
$1938 / 1939$
\end{tabular} & 3 \\
\hline & & $\begin{array}{l}\text { elementarny język } \\
\text { ormiański }\end{array}$ & $1934 / 1935$ & 2 \\
\hline & & $\begin{array}{l}\text { zaawansowany język } \\
\text { ormiański }\end{array}$ & $1934 / 1935$ & 1 \\
\hline 4. & Jerzy Kuryłowicz & $\begin{array}{l}\text { język staroormiański na } \\
\text { tle porównawczym }\end{array}$ & $\begin{array}{l}1935 / 1936 \\
1938 / 1939\end{array}$ & 2 \\
\hline
\end{tabular}

Źródło: DALO: f. 26, op. 5, sp. 541, teczka personalna Bogdana Dawidowicza; DALO: f. 26, op. 5, sp. 841, teczka personalna Garabeda Keupruliana; C.K. Uniwersytet imienia Ce- 
sarza Franciszka I we Lwowie. Program wykładów w pótroczu zimowym 1904/1905-1918/1919, Lwów 1904-1918; C.K. Uniwersytet imienia Cesarza Franciszka I we Lwowie. Program wykładów w pótroczu letnim 1904/1905-1917/1918, Lwów 1905-1918; Uniwersytet we Lwowie. Program wykładów w pótroczu zimowym 1919/1920, Lwów 1919; Uniwersytet we Lwowie. Program wykładów w pótroczu letnim 1918/1919-1919/1920, Lwów 1919-1920; Uniwersytet Jana Kazimierza we Lwowie. Program wyktadów w 1 i 2 trymestrze roku akademickiego 1920/1921-1922/1923, Lwów 19201922; Uniwersytet Jana Kazimierza we Lwowie. Program wykładów w 3 trymestrze roku akademickiego 1920/1921-1922/1923, Lwów 1921-1923; Uniwersytet Jana Kazimierza we Lwowie. Program wykładów na rok akademicki 1923/1924-1938/1939, Lwów 19231938; Uniwersytet Jana Kazimierza we Lwowie. Program wykładów na Wydziale Filozoficznym w trymestrze 3 roku akademickiego 1923/1924, Lwów 1924.

\section{Bibliografia}

\section{Źródla archiwalne}

Archiwum Główne Akt Dawnych w Warszawie: zespół 304, C.K. Ministerstwo Wyznań i Oświaty w Wiedniu, sygn. 116u, Armenische sprache (1904)

Archiwum Fundacji Kultury i Dziedzictwa Ormian Polskich w Warszawie: Spuścizna abpa Józefa Teodorowicza, t. 128, korespondencja

[Derżawnyj] Державний архів Львівської області we Lwowie: f. 26, op. 5, sp. 334, teczka personalna Andrzeja Gawrońskiego; sp. 541, teczka personalna Bogdana Dawidowicza; sp. 841, teczka personalna Garabeda Keupruliana; sp. 1023, teczka personalna Jerzego Kuryłowicza; f. 26, op. 7, sp. 508, protokoły posiedzeń Rady Profesorów [Wydziału Filozoficznego Uniwersytetu Lwowskiego] w roku akademickim 1903/04; sp. 509, sprawozdania z pracy seminariów, korespondencja z Ministerstwem Wyznań i Oświaty [w Wiedniu], Namiestnictwem we Lwowie o powołaniu nowych katedr, wprowadzeniu języka ormiańskiego, warunkach dopuszczenia kobiet do studiowania farmacji, uczestnictwa w kongresie archeologów i in[ne] materiały dotyczące spraw naukowych i porządku pracy administracyjnej; sp. 809, autobiografie i biografie 23 profesorów Wydziału Filozoficznego Chybińskiego, Ułaszyna, Kleinera, Bulandy, Czekanowskiego, Fischera, Steinhausa i in[nych]; sp. 1365, protokoły (kopie) posiedzeń Rady Wydziału [Filozoficznego] za rok akademicki 1933/34; f. 26, op. 15, sp. 1007, katalog studentów I-IV roku (1906-1907)

\section{Źródla drukowane}

C. K. Uniwersytet imienia Cesarza Franciszka I we Lwowie. Program wykładów w półroczu zimowym 1904/1905-1918/1919, Lwów 1904-1918

C. K. Uniwersytet imienia Cesarza Franciszka I we Lwowie. Program wykładów w pótroczu letnim 1904/1905-1917/1918, Lwów 1905-1918

Catalogus universi cleri et schematismus archidioecesis Leopoliensis ritus armeno-catholici Anno 1905, Leopoli 1905

Donigiewicz S., Gramatyka języka ormiańskiego, 1, Język staroormiański, Lwów 1929 (reprint: Gliwice 1973), powielany rękopis

Drugi lektorat języka ormiańskiego w Polsce, „Gregoriana”, 1936, 3-4, s. 157 
Janusz B., O potrzebie założenia we Lwowie „Ormiańskiego Muzeum Diecezjalnego”, w: Pamiętnik V. Zjazdu Delegatów Zwiąku Muzeów w Polsce odbytego w Tarnowie $w$ dn [iach] 12-13 czerwca 1930, red. M. Piotrowski, Kraków 1930, s. 36-41

Kronika, „Posłaniec św. Grzegorza”, 5, 1931, 50, s. 120

Kronika. Lektorat języka ormiańskiego, „Posłaniec św. Grzegorza”, 4, 1930, 40-41, s. 164

Lektorat języka ormiańskiego na U[niwersytecie] J[ana] K[azimierza], „Gregoriana”, 1938, 4, s. 274

Sprawozdanie z działalności Wydziału Humanistycznego Uniwersytetu J. Piłsudskiego za rok akad[emicki] 1935-1936, Warszawa 1937

Uniwersytet Jana Kazimierza we Lwowie. Program wykładów na rok akademicki 1923/1924-1938/1939, Lwów 1923-1938

Uniwersytet Jana Kazimierza we Lwowie. Program wykładów na Wydziale Filozoficznym $w$ trymestrze 3 roku akademickiego 1923/1924, Lwów 1924

Uniwersytet Jana Kazimierza we Lwowie. Program wykładów w 1 i 2 trymestrze roku akademickiego 1920/1921-1922/1923, Lwów 1920-1922

Uniwersytet Jana Kazimierza we Lwowie. Program wykładów w 3 trymestrze roku akademickiego 1920/1921-1922/1923, Lwów 1921-1923

Uniwersytet we Lwowie. Program wykładów w pótroczu letnim 1918/1919-1919/1920, Lwów 1919-1920

Uniwersytet we Lwowie. Program wykładów w pótroczu zimowym 1919/1920, Lwów 1919

Wójcik-Keuprulian B., Korespondencja do Szwajcarii. Listy do Henryka Opieńskiego (1925-37) i Ludwika Bronarskiego (1929-38), oprac. M. Sieradz, Warszawa 2018

Z kroniki żałobnej. Śp. inż. Garabed Keuprulian, „Posłaniec św. Grzegorza”, 13, 1939, 3, s. 130-131

Z piśmiennictwa. Gramatyka języka ormiańskiego, „Posłaniec św. Grzegorza”, 4, 1930, 36-37, s. 103

Z piśmiennictwa. Gramatyka języka ormiańskiego, 1, Język staroormiański, „Posłaniec św. Grzegorza", 4, 1930, 32-33, s. 20

Z życia naszego Związu, „Posłaniec św. Grzegorza”, 12, 1938, 4, s. 82-83

\section{Opracowania}

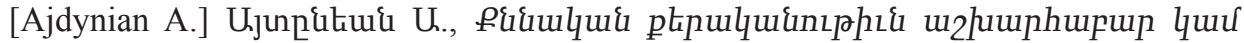
upnh hujkpli jlaqnıh [Krytyczna gramatyka świeckiego, czyli współczesnego języka ormiańskiego], પ,hłququ [Wiedeń] 1866

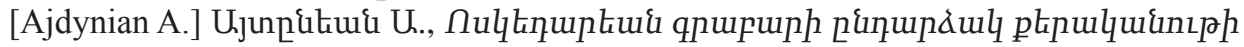
$\llcorner\{$, [Obszerna gramatyka staroormiańskiego języka złotego wieku], પ, htıీquu [Wiedeń] 1884

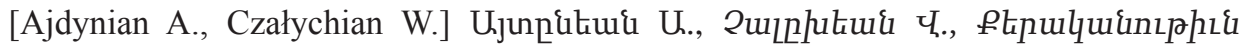

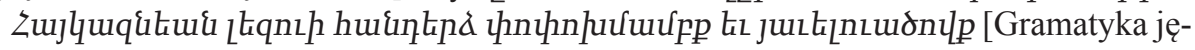
zyka narodu ormiańskiego wraz ze zmianami i uzupełnieniami], પ,htiquu [Wiedeń] 1885

Barącz S., Rys dziejów ormiańskich, Tarnopol 1869

Bibliografia prac prof. dra Eugeniusza Stuszkiewicza (1927-1973), oprac. A. i E. Ługowscy, w: Księga pamiątkowa ku czci Eugeniusza Stuszkiewicza, red. J. Reychman, Warszawa 1974, s. 9-19 
Brugmann K., Delbrück B., Grundriß der vergleichenden Grammatik der indogermanischen Sprachen, Strassburg 1886-1900, https://doi.org/10.1515/9783111600550

Donigiewicz S., Dzieje nauczania języka ormiańskiego w Polsce i historia lektoratu tegoż języka w Uniwersytecie J[ana] K[azimierza] we Lwowie, „Posłaniec św. Grzegorza”, 7, 1933, 3-4, s. 35-38

Donigiewicz S., Śp. Ksiadz Bogdan Dawidowicz, „Rocznik Orientalistyczny”, 1934, 8, S. 201-202

Donigiewicz S., Śp. Prof. dr Roman Baracz, „Posłaniec św. Grzegorza”, 5, 1931, 44, s. $3-7$

Gawroński A., Język Ormian polskich, w: Język polski i jego historia z uwzględnieniem innych języków na ziemiach polskich, 2, red. H. Ułaszyn et al., Kraków 1915, s. 452-455

Gramatyka języka ormiańskiego, „Posłaniec św. Grzegorza”, 3, 1929, 31, s. 176

Heinz A., Profesor Jerzy Kuryłowicz. Wspomnienie pośmiertne, „Biuletyn Polskiego Towarzystwa Językoznawczego", 37, 1980, s. 3-7

Hübschmann H., Armenische Grammatik, Leipzig 1895

Hübschmann H., Armenische Studien, Leipzig 1883

Kainz C., Praktische Grammatik der armenischen Sprache für den Selbstunterricht. 1, Classische Sprache, 2, Neu-armenische Sprache mit einem neu-armenisch-deutschen und deutsch-neu-armenischen Wörterbuch und zahlreichen Lesestücken, Wien 1891

Kajetanowicz D., La cathédrale arménienne de Lwów et son entourage. Guide, Lwów 1931

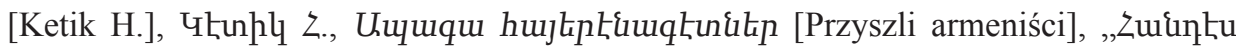
Uúupliuu” [Handes Amsorya], 1905, 1, s. 28-32

Kozarynowa Z., Andrzej Gawroński (1885-1927), „Znak”, 34, 1982, 6, s. 579-604

Krzyżowski T., Archidiecezja lwowska obrządku ormiańskokatolickiego w latach 19021938, Kraków 2020

Lewicki K., Dawidowicz Bogdan, w: Polski słownik biograficzny, 4, Kraków 1938, s. 464

Meillet A., Esquisse d'une grammaire comparée de l'arménien classique, Vienne 1903

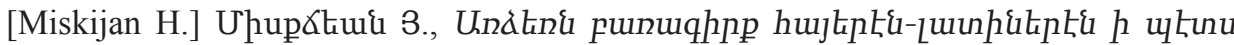
пupngurg (Manuale lexicon Armeno-Latinum. Ad usum scholarum), Znnu [Rzym] 1887

Mojzesowicz M., Dawna szkoła ormiańska w Kutach, „Posłaniec św. Grzegorza”, 1, 1927, 7, s. 7-9

Nitsch K., Andrzej Gawroński, „Przegląd Współczesny”, 6, 1927, 58, s. 177-191

Nitsch K., Gawroński Andrzej (1885-1927), w: Polski słownik biograficzny, 7, Kraków 1948-1958, s. 325-328

Pedersen H., Armenisch und die Nachbarsprachen, „Zeitschrift für vergleichende Sprachforschung", 39, 1904, s. 334-485

Pedersen H., Zur armenischen Sprachgeschichte, „Zeitschrift für vergleichende Sprachforschung", 38, 1902, s. 194-240

Petermann J. H., Brevis linguae armeniacae: grammatica, litteratura, chrestomathia cum glossario: in usum praelectionum et studiorum privatorum, Berolini 1872

Pisowicz A., Gramatyka ormiańska (grabar - aszcharabar), Kraków 2014, https://doi. org/10.12797/8371884893

Pisowicz A., Znajomość języka i literatury ormiańskiej w Polsce w XIX i XX wieku, „Przegląd Orientalistyczny”, 1999, 3-4, s. 187-194 
Słownik ormiańsko-polski, „Posłaniec św. Grzegorza”, 12, 1938, 4, s. 82

Słuszkiewicz E., Andrzej Gawroński (w czterdziestolecie zgonu), w: Szkice z dziejów polskiej orientalistyki, red. J. Reychman, Warszawa 1969, s. 173-215

Słuszkiewicz E., O charakterze języka ormiańskiego, jego pokrewieństwa z innymi językami i fazach rozwojowych, „Posłaniec św. Grzegorza”, 8, 1934, 3-4, s. 21-27

Słuszkiewicz E., Wspomnienie o Andrzeju Gawrońskim. W dziesięciolecie zgonu, „Rocznik Orientalistyczny", 1936, 12, s. 216-230

Stopka K., Nieznane karty z dziejów szkolnictwa Ormian polskich. Szkoła kościelna (tybradun) do XVII wieku, w: Virtuti et ingenio. Księga pamiatkowa dedykowana Profesorowi Julianowi Dybcowi, red. A. K. Banach, Kraków 2013, s. 477-498

Stopka K., Tożsamość Ormian w Galicji, „Zeszyty Naukowe Uniwersytetu Jagiellońskiego”, „Prace Historyczne”, 2017, 2, s. 335-355, https://doi.org/10.4467/2084406 9PH.17.018.6261

Śp. Andrzej Gawroński, „Rocznik Orientalistyczny”, 1926, 4, [wyd. 1928], s. I-VII

Tryjarski E., Eugeniusz Stuszkiewicz - najwybitniejszy armenista polski (1901-1981), „Przegląd Orientalistyczny”, 1983, 1-4, s. 11-19

Tryjarski E., Ze studiów nad rękopisami i dialektem kipczackim Ormian polskich, 2, O nauce języków obcych $w$ Kolegium teatyńskim we Lwowie, ,Rocznik Orientalistyczny", 1960, 23, 2, s. 30-55

\section{Tomasz Krzyżowski, Teaching the Armenian language at the University of Lwów in the years 1904-1939}

Summary: The first attempts to introduce an Armenian language course at the University of Lwów were made at the beginning of the 20th century. The authorities of the Faculty of Philosophy obtained the consent of the Ministry of Religious Affairs and Education in Vienna to open a course of Old and New Armenian, which was conducted in the years 1904-1933 by Rev. Bogdan Dawidowicz. The classes were attended by seminarians of the Armenian-Catholic archdiocese, linguists, orientalists and others interested in Armenian issues. Typically, two hours a week were allocated to these classes. Students learned Armenian grammar and literature, including the works of Movses Khorenatsi and Raffi (Hakob Melik Hakobian), as well as with the specific conditions of the development of the Armenian language in Poland. After the death of Rev. Dawidowicz, Garabed Keuprulian continued the course, focusing on West Armenian. In the interwar period, lectures on Armenian language and classical literature were conducted by professor Andrzej Gawroński from the Institute of Oriental Studies, while professor Jerzy Kuryłowicz taught Old Armenian from the historical and comparative perspective. During the discussed period, the university community in Lviv and the activists of the Archdiocese Union of Armenians were also involved in publishing aimed at popularizing knowledge and broadening the studies in the field of the Armenian language.

Keywords: Armenian language, University of Lwów, Armenian studies, Bogdan Dawidowicz, Garabed Keuprulian, Andrzej Gawroński, Jerzy Kuryłowicz 


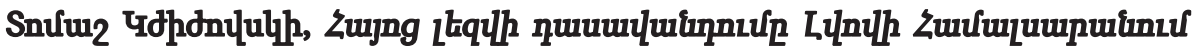 1904-1939 $\mathrm{pp}$.}

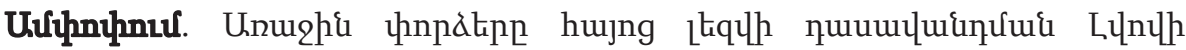

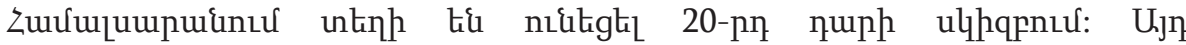

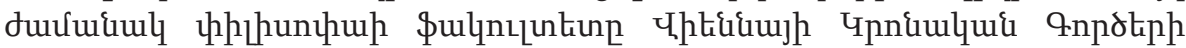

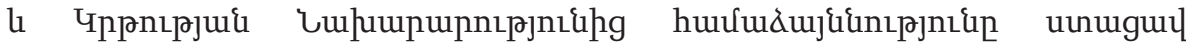

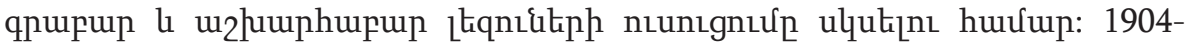

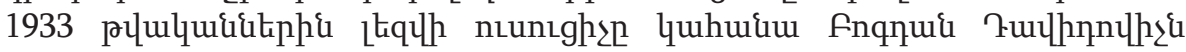

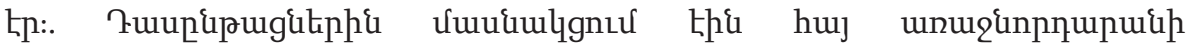

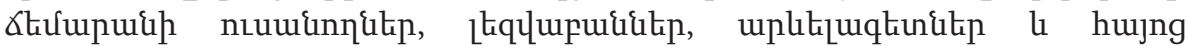

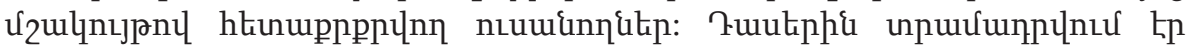

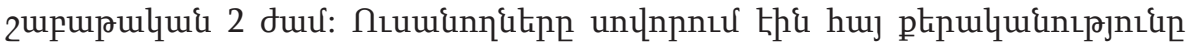

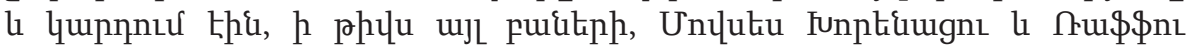

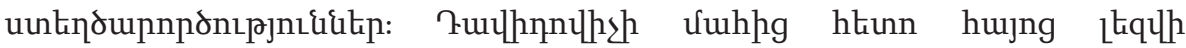

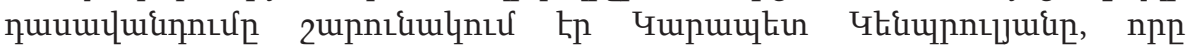

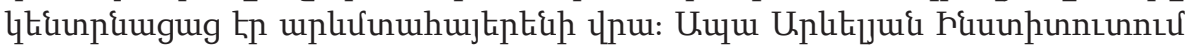

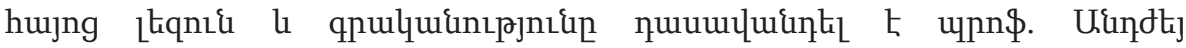

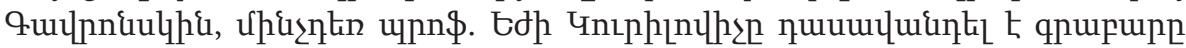

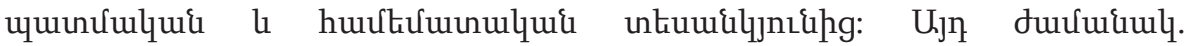

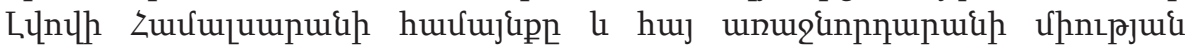

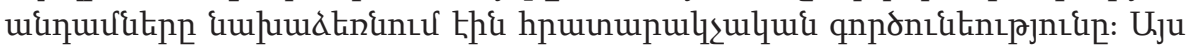

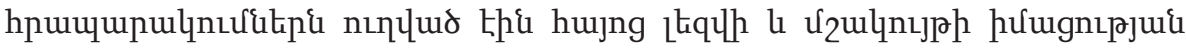

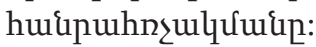

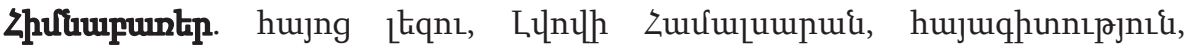

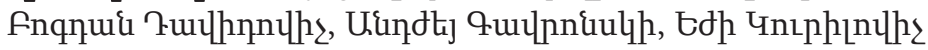




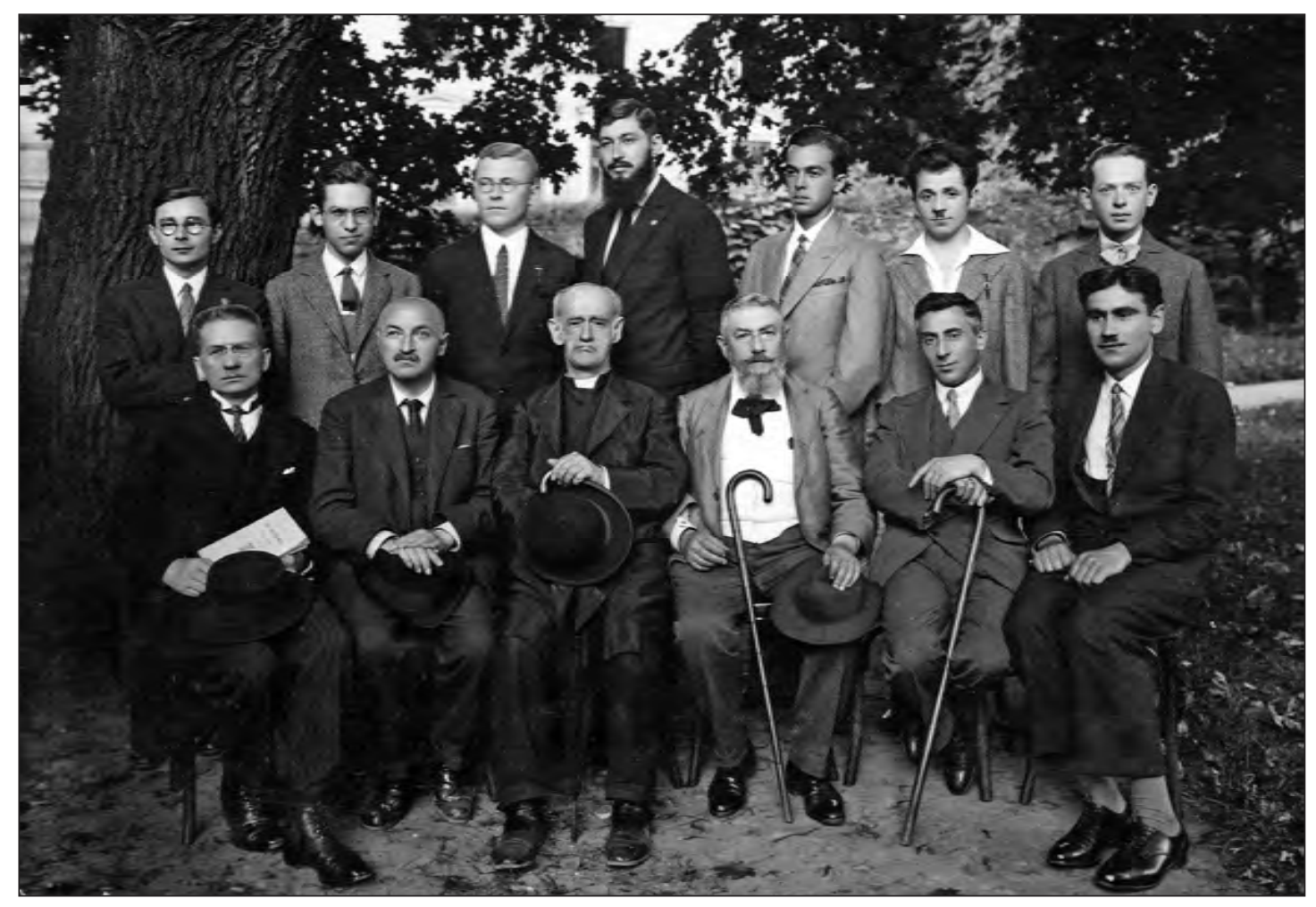

1. Uczestnicy lektoratu języka ormiańskiego na Uniwersytecie Jana Kazimierza we Lwowie w latach 1904/05-1929/30 z okazji dwudziestopięciolecia wprowadzenia lektoratu. Od lewej siedzą: Bohdan Janusz, prof. Jakub Bohosiewicz, ks. Bogdan Dawidowicz, prof. Roman Barącz, Jakub Moszoro, Mikołaj Mojzesowicz; od lewej stoją: Kajetan Zachariasiewicz, Stanisław Zachariasiewicz, Krzysztof Donigiewicz, Dominik Janowicz, Zbigniew Bober, Stanisław Donigiewicz, Franciszek Zachariasiewicz; Archiwum Fundacji Kultury i Dziedzictwa Ormian Polskich w Warszawie 


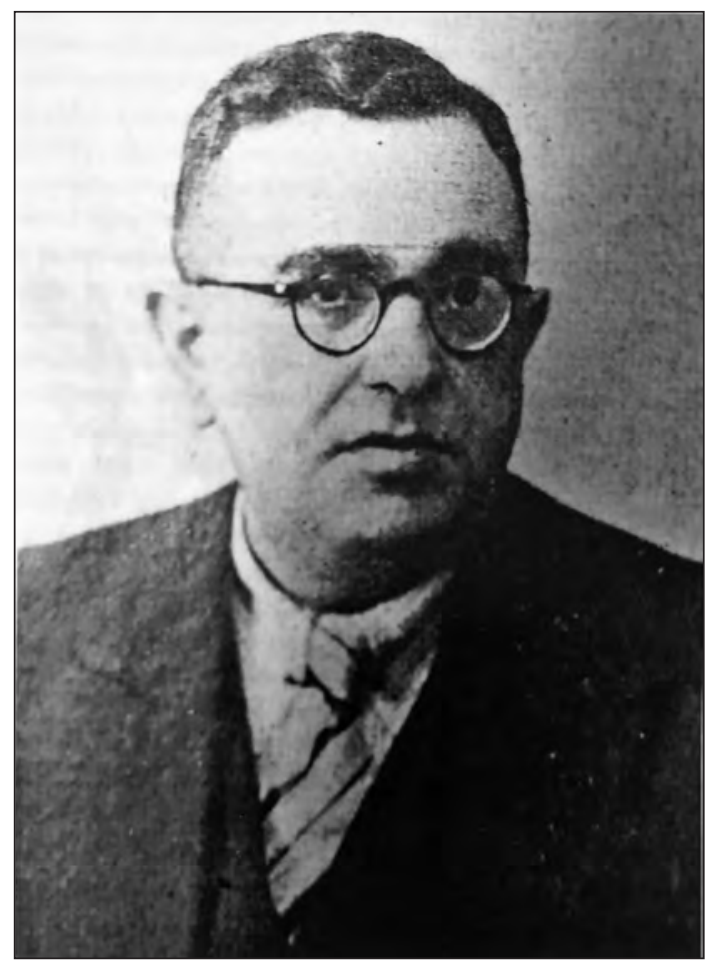

2. Garabed Keuprulian (1884-1939); „Posłaniec św. Grzegorza” 13, 1939, 3

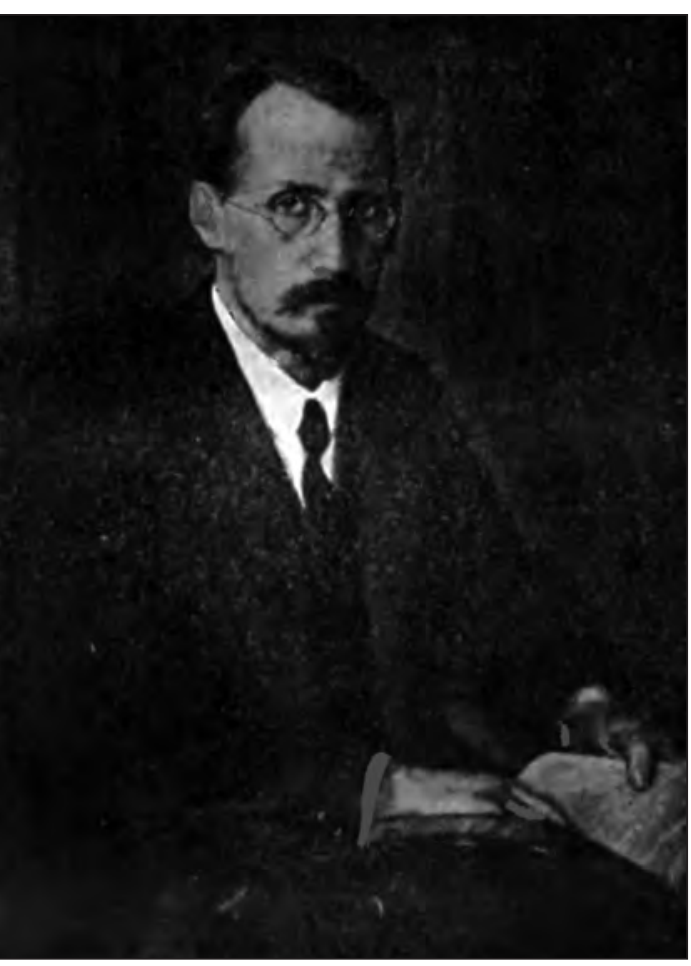

3. Prof. Andrzej Gawroński, fot., domena publiczna 


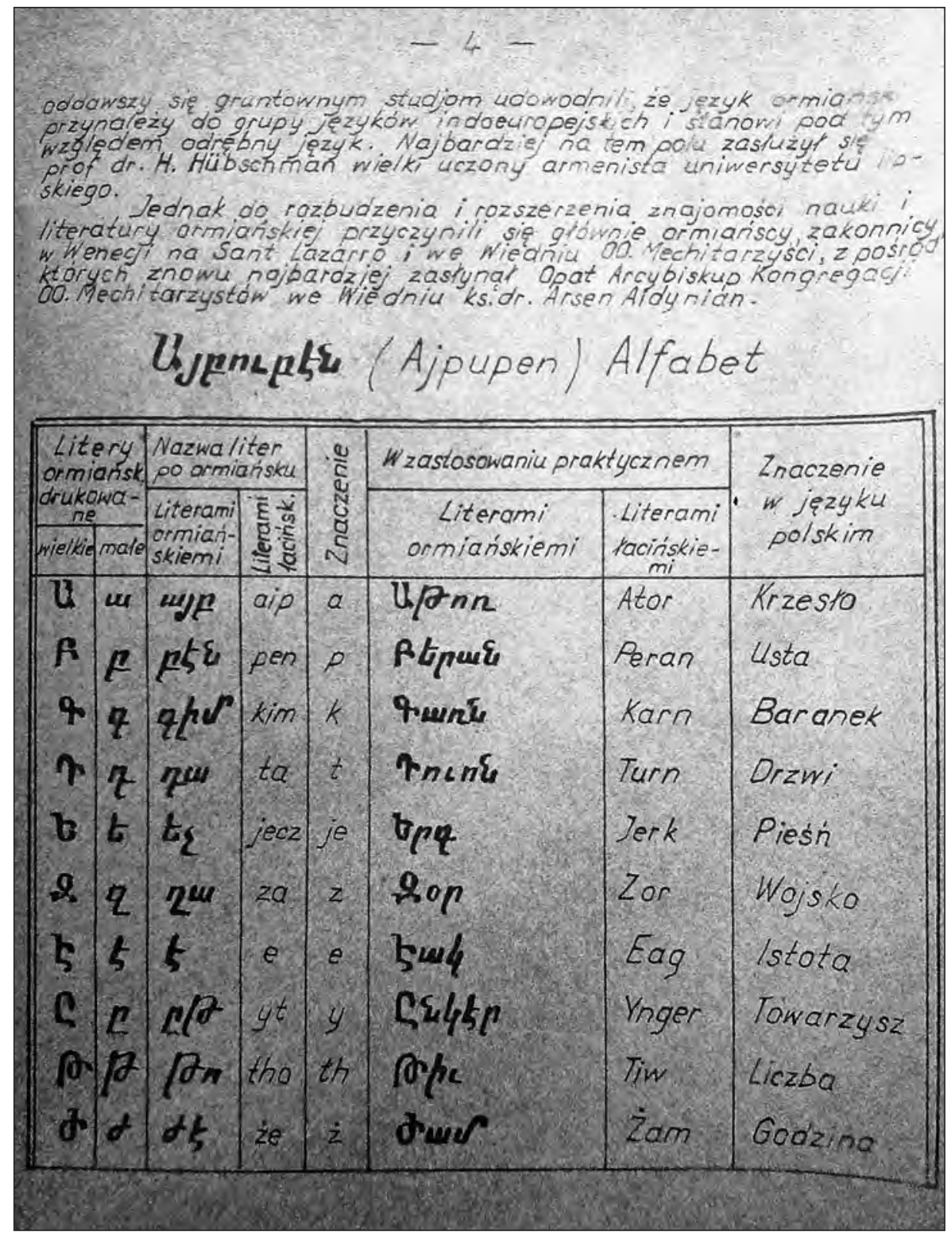

4. Fragment Gramatyki języka ormiańskiego autorstwa Stanisława Donigiewicza, Lwów 1929 (reprint 1973); zbiory autora 